Economic and Environmental Geology

Research Paper

\title{
Deterioration Diagnosis and Evaluation of Physical Properties in the Dinosaur Footprint Fossils in Cheongsong Sinseongri, Korea, for the Conservation Plans
}

\author{
Hye Ri Yang, Chan Hee Lee*, Jun Hyoung Park \\ Department of Cultural Heritage Conservation Sciences, Kongju National University, Gongju 32588, Korea \\ ${ }^{*}$ Corresponding author : chanlee@kongju.ac.kr
}

\section{ARTICLE INFORMATION}

Manuscript received 3 May 2021

Received in revised form 17 May 2021

Manuscript accepted 19 May 2021

Available online 28 June 2021

DOI : http://dx.doi.org/10.9719/EEG.2021.54.3.311

\section{Research Highlights}

- The Sinseongri dinosaur fossils site occurred in 262 footprints and 15 trackways.

- Scientific investigation and digital recordings studied to stabilize the fossils site.

- More than half of footprints in need of reinforcement and treatment is suggested.

\begin{abstract}
The Sinseongri site contains at least eleven theropod trackways, three sauropod trackways, and one or more ornithopod walkways of dinosaur footprints. The host rock at the site is primarily siltstone and mudstone, but thermal alterations have metamorphosed it into hornfels. Except for micro cracks and exfoliations, joint systems in various directions appeared on the surface of the fossils site and showed a low share of all damage factors. The host rocks in the fossils site demonstrated relatively high physical properties as a result of ultrasonic velocity and were classified as stable. More than half of the fossils required reinforcement to control the progression of cracks if the type of conservation treatment was subdivided according to the damage type of dinosaur footprint fossils. The white paint used to visualize the footprints seems to deteriorate, allowing rock debris to spill out and causing damage to the fossil site, and alternative visualization schemes should be considered.
\end{abstract}

Keywords : dinosaur footprint fossils, siltstone and mudstone, damage factors, ultrasonic velocity, conservation treatment type

Citation: Yang, H.R., Lee, C.H., Park, J.H. (2021) Deterioration Diagnosis and Evaluation of Physical Properties in the Dinosaur Footprint Fossils in Cheongsong Sinseongri, Korea, for the Conservation Plans. Korea Economic and Environmental Geology, v.54, p.311-330, doi:10.9719/EEG2021.54.3.311.

This is an Open Access article distributed under the terms of the Creative Commons Attribution Non-Commercial License (http://creativecommons.org/ licenses/by-nc/3.0) which permits unrestricted non-commercial use, distribution, and reproduction in any medium, provided original work is properly cited. pISSN 1225-7281; eISSN 2288-7962/C2021 The KSEEG. Printed by Hanrimwon Publishing Company. All rights reserved. 


\section{연구논문}

\section{보존방안 수립을 위한 청송 신성리 공룡발자국 화석지의 손상도 진단 및 물성평가}

양혜리 · 이찬희 ${ }^{*}$. 박준형

공주대학교 문화재보존과학과

*책임저자 : chanlee@kongju.ac.kr

\section{요 약}

청송 신성리 공룡발자국 화석지에는 최소한 수각류 보행렬 11 개, 용각류 보행렬 3 개 및 조각류 보행렬 1 개 이상 존재하여, 국 내 다른 공룡발자국 화석지에 비해 수각류 보행렬의 밀집도가 높다. 공룡발자국의 모암은 미사암과 이암의 암상을 보이나 전체 적으로 열변질을 받아 혼펠스화되어 있다. 이 화석지의 표면에는 다양한 방향의 절리가 나타나며 미세균열과 박락을 제외하면 모든 손상요인에서 낮은 점유율을 보였다. 초음파 속도 측정 결과, 화석지의 암석은 비교적 건전한 물성을 보여 안정적인 것으 로 평가되었다. 공룡발자국 화석의 손상형태에 따라 보존처리 유형을 세분하면, 균열의 진전을 제어할 수 있는 강화처리가 필 요한 발자국화석이 절반 이상의 비율을 보였다. 또한 발자국의 가시화를 위해 도포한 흰색 페인트가 열화되면서 암편 탈락을 유발하여 오히려 화석의 손상을 촉진하는 것으로 나타나, 이를 대체할 방안이 검토되어야 할 것이다.

주요어 : 공룡발자국 화석지, 미사암 및 이암, 손상요인, 초음파 속도, 보존처리 유형

\section{1. 서 언}

지질시대의 공룡발자국 화석은 노출되기 이전에는 지 층의 하부에 분포하기 때문에 단층이나 습곡 등 조산운 동에 의한 변형을 제외하면 비교적 오랜 기간 안정적으 로 보존되어 왔다. 그러나 지층의 융기 등 지질학적 변 형과정 이후 침식작용이나 발굴 등에 의해 화석산지가 외부 환경에 노출되면 다른 석조문화재와 거의 동일하게 지속적인 풍화와 침식 및 인위적인 훼손을 받아 원형을 완전하게 유지하기 어렵다.

국내외를 막론하고 석조문화유산의 보존을 위해 다양 한 연구가 진행되어 왔으며, 정밀진단을 통한 손상도 평 가와 이를 반영한 보존처리 및 관리방안도 체계적으로 정립되고 있다. 그러나 화석지와 같은 자연유산에 대한 보존과학적 연구는 많지 않다(Lee et al., 2012; Lee et al., 2019; 2020; Yoo et al., 2012). 이 연구의 대상인 청 송 신성리 공룡발자국 화석지는 현황과 사이트 환경, 고 생물 및 암석학적 특성 등이 상세히 보고되었으나 $(\mathrm{Kim}$ et al., 2019), 보존과학적 연구는 수행된 바 없다.

화석지의 보존관리를 위해서는 환경에 따른 현황 기록 과 함께 비파괴 정밀진단과 암석학적 손상 특성을 반영 한 보존처리 설계 및 과학적 적용이 필요하다. 신성리 공
룡발자국 화석지의 노두는 2003년 태풍 매미의 영향으로 도로변 급사면을 덮고 있던 암석과 휽이 쓸려 내려가면 서 발자국화석이 발달한 성층면이 드러나게 되었다(Fig. 1A). 이후 화석지의 보존을 위한 기초조사를 통해 발자국 보 행렬에 대한 기재가 수행되어 용각류, 조각류 및 다수의 수각류 보행렬 화석이 동시에 보고되었다(Moon, 2010; Kim et al., 2019).

신성리 공룡발자국 화석은 발굴 이후 현재까지 보호각 없이 대기환경에 노출되어 비교적 단기간에 걸친 기후변 화 및 수분유입 등으로 인해 자연적 풍화가 지속적으로 진행되고 있는 상태이다(Fig. 1B). 또한 대부분의 공룡발 자국 화석이 산출되는 지층은 자연적 및 인위적으로 손 상되고 있으며 보존상태가 불량하여 일부 발자국은 원형 의 식별이 불분명할 정도이다.

따라서 이 연구에서는 신성리 공룡발자국 화석지의 암 석학적 특성과 풍화훼손도 평가 및 물성분석을 통해 정 밀진단을 수행하였으며, 이를 바탕으로 화석지의 보존처 리와 장기보존 방안을 검토하였다. 또한 화석지의 올바 른 관리를 위해 현재의 보존상태에 대한 정확한 기초자 료를 구축하였다. 이 연구에서 수집한 신성리 공룡발자 국에 대한 모든 결과와 디지털기록은 향후 안정적이고 장기적인 보존관리의 매우 중요한 근거가 될 것이다. 

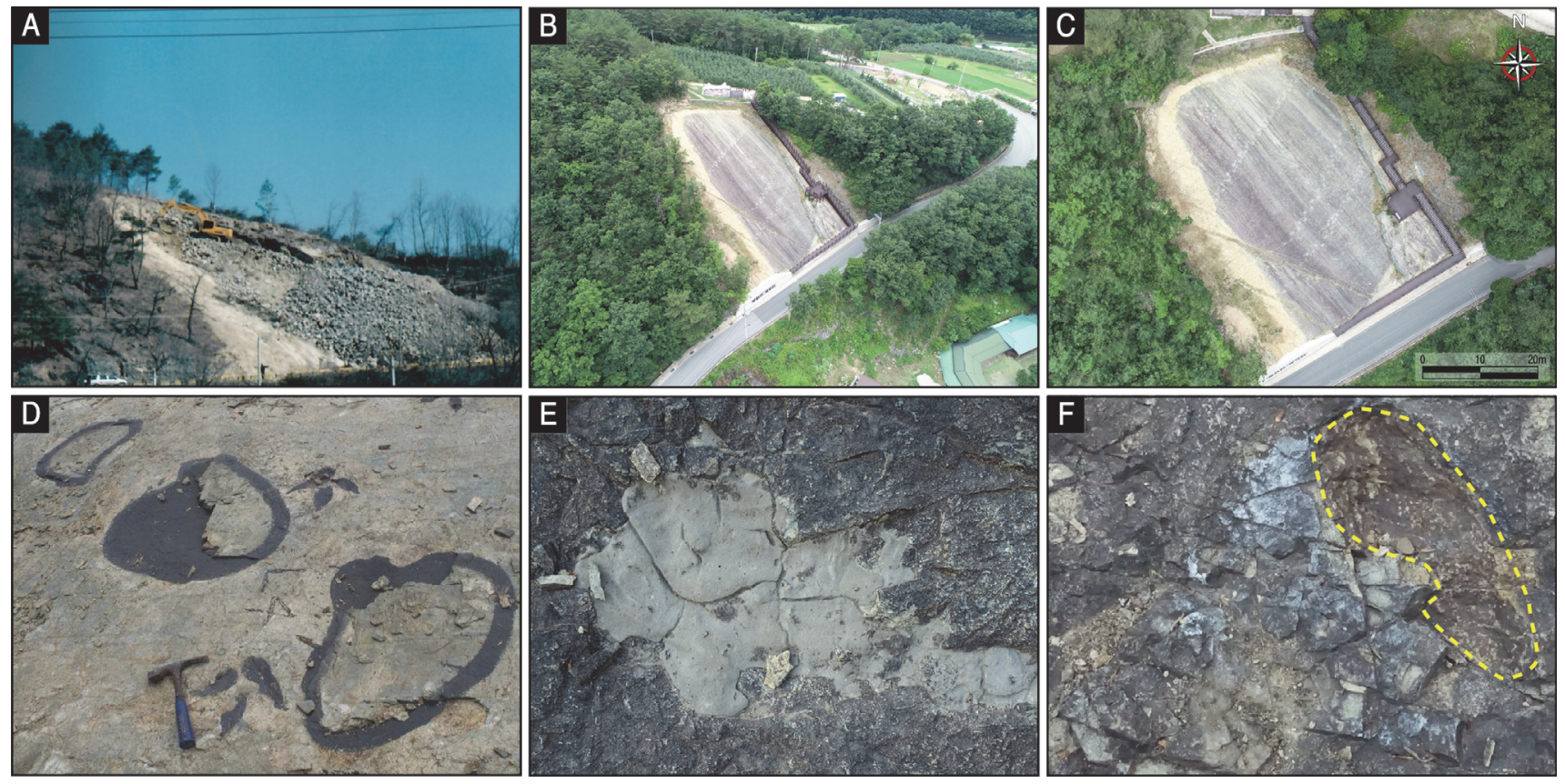

Fig. 1. Comparative photographs and conservation status of the representative dinosaur footprint fossils in the study area. (A) Recovery site after the 2003 landslide. (B) Site location and environment. (C) Results of alignment to the true north of Orthomosaic image created by UAV (unmanned aerial vehicle) photogrammetry. (D) Sauropod footprint of trackway S2 in 2011 academic survey (Moon, 2011). (E, F) Surface contaminants, blistering and exfoliation on the footprint fossils.

\section{2. 현황 및 연구방법}

\section{1. 현 황}

신성리 공룡발자국 화석지는 약 $2,400 \mathrm{~m}^{2}$ 에 달하는 암 반의 사면에 용각류와 수각류 및 조각류 발자국 화석이 분포한다. 이 암반은 백악기 경상누층군의 사곡층에 해 당하며, 공룡발자국 화석은 퇴적암의 성층면에 보행렬을 이루며 나타난다(Kim et al., 2019). 이들의 전반적인 보 존상태는 양호하지 않지만 높은 밀집도를 보인다(Fig. 1C).

이 화석지의 성층면에서 관찰되는 공룡발자국들은 손 상정도가 심한 것이 많아 발자국의 수를 정확하게 파악 하기 어려우나, 최소한 수각류 보행렬이 11 개, 용각류 보 행렬이 3 개, 조각류 보행렬이 1 개 이상 존재하는 것으로 확인되었다. 이와 같은 구성은 국내 다른 공룡발자국 화 석지에 비해 특히 수각류 보행렬이 높은 비중을 차지하 는 것이다.

이 화석지에는 2010년 학술조사 당시 발자국의 형상을 식별하기 위해 노출된 공룡발자국의 모양을 따라 점토나 페인트 또는 분필을 이용하여 형태를 표시하였다(Fig. 1D). 현재 대부분의 발자국 화석에는 페인트와 점토 흔적이 남아있다(Fig. 1E). 또한 일부 화석의 표면에는 발자국 면 적의 절반 이상에 해당하는 박리와 박락이 나타나기도 한다(Fig. $1 \mathrm{~F})$. 이와 같은 다양한 손상양상은 시간이 지
남에 따라 점차 심화될 것으로 보이며, 장기적 안정성에 도 영향을 미칠 수 있다.

용각류 발자국화석은 비교적 선명하게 보존되어 있으 나 가장자리를 따라 부분적인 손상이 발생하여 희미한 경우도 있다(Fig. 2A, 2B). 조각류 보행렬은 2족 보행의 특성을 나타나고 대체로 일정한 방향성을 보이며 산출된 다(Fig. $2 \mathrm{C}$ ). 이 조각류 보행렬을 구성하는 대부분의 발 자국은 크기와 모양이 거의 비슷하다(Fig. 2D).

수각류 보행렬의 경우 일정한 방향성을 보이지 않고 산 발적으로 분포하며 각각의 보행렬을 구성하는 발자국의 크기와 모양은 다양하다. 수각류 발자국은 3 개의 발가락 이 선명하게 나타나며 발톱자국이 관찰되기도 한다 (Fig. 2E 2G). 용각류 보행렬 화석은 대체로 일정한 방향 성을 보이며(Fig. 2H, 2I), 뒷발은 비교적 선명하지만 앞 발은 불분명하다. 이 연구에서는 신성리 화석지에서 산 출되는 공룡발자국의 정확한 분포를 파악하기 위해 정밀 조사를 수행하였다.

\section{2. 연구방법}

이 연구에서는 신성리 공룡발자국 화석지의 보존상태 를 종합적으로 검토하기 위해 암석학적 특성, 비파괴 정 밀진단, 초음파 물성분석 및 표면의 손상정도를 평가하 였다. 또한 연구대상 화석지의 지리정보 구축과 현황을 

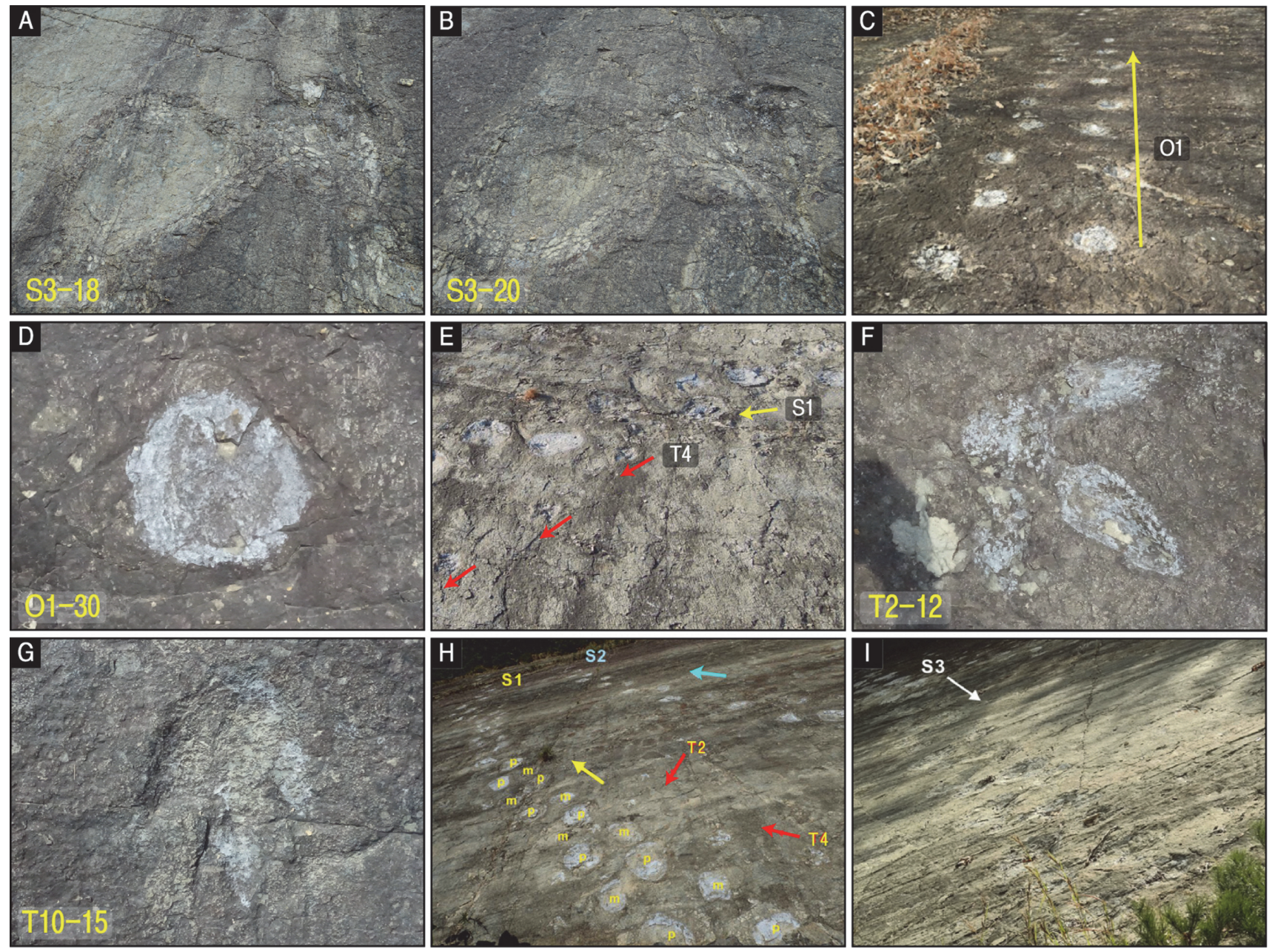

Fig. 2. Occurrences of sauropod, ornithopod, and theropod trackways in the study area. (A) The 18th sauropod footprint of trackway S3. (B) The 20th sauropod footprint of trackway S3. (C) Ornithopod footprint of trackway O1 (Kim et al., 2019). (D) The 30th ornithopod footprint of trackway O1. (E) Theropod footprint of trackway T4 (Kim et al., 2019). (F) The 12th theropod footprint of trackway T2. (G) The 15th theropod footprint of trackway T10. (H, I) Sauropod footprint of trackway S1, S2, and S3 (modified from Kim et al., 2019).

파악하기 위해 지상기준점 및 무인항공사진 측량을 바탕 으로 디지털기록화를 수행하였다.

우선 화석지의 공간정보 구축을 위해 지상기준점 $(\mathrm{GCP})$ 을 측량하였으며, 장비는 KOSECO사의 Hi-Target V100 을 활용하였다. 기준점은 별도의 영구표지 대신 주변에 장애물이 없고 시야 확보가 가능한 임의의 5 지점을 설정 하였다(Table 1). 이 결과로 볼 때 신성리 공룡발자국 화 석지는 표고 약 306 336m 사이에 위치한다. 이 지상기 준점을 무인항공사진측량 입체모델의 절대위치 보정에 활용하여 화석지 지형측량의 정확도와 신뢰도를 높였다.

또한 화석지의 조사에 앞서 주변 환경과 산출상태에 대 한 기록보존을 위해 무인항공사진측량을 실시하였다. 촬 영 결과에 대한 영상처리는 $\mathrm{SFM}$ 알고리즘이 적용된 Agisoft 사의 Metashape Professional 소프트웨어를 이용
하였다. 이를 바탕으로 공룡발자국 화석의 상세 분포도 및 실측도면을 제시하였다. 이 연구에서 취득한 영상자 료와 선행 자료를 비교분석하여 기존의 화석지 도면에서 발자국 위치를 수정 및 보완하였다(Fig. 3).

신성리 공룡발자국 화석의 암석 및 광물학적 특징을 상 세히 분석하기 위해 화석지에서 탈락한 시료를 수습하여 실체(Nikon, SNZ1000) 및 편광현미경(Nikon, Eclipse E $600 \mathrm{~W})$ 으로 관찰하였다. 조암광물의 동정은 Rigaku사의 $\mathrm{DMAX} 2000 \mathrm{X}$-선 회절분석기를 이용하였다. 이때 타겟 으로 사용한 $\mathrm{X}$-선은 $\mathrm{CuK} \alpha$ 이며, 양극의 가속전압 및 필 라멘트 전류는 $40 \mathrm{kV}$ 와 $100 \mathrm{~mA}$ 로 설정하여 $1 \% \mathrm{~min}$ 의 조 건으로 $3 \sim 60^{\circ}$ 의 범위를 분석하였다.

화석지 표면은 암석의 물리적 특성과 이차적 오염 및 장기간의 노출에 따른 다양한 이물질의 흔적이 산재한다. 


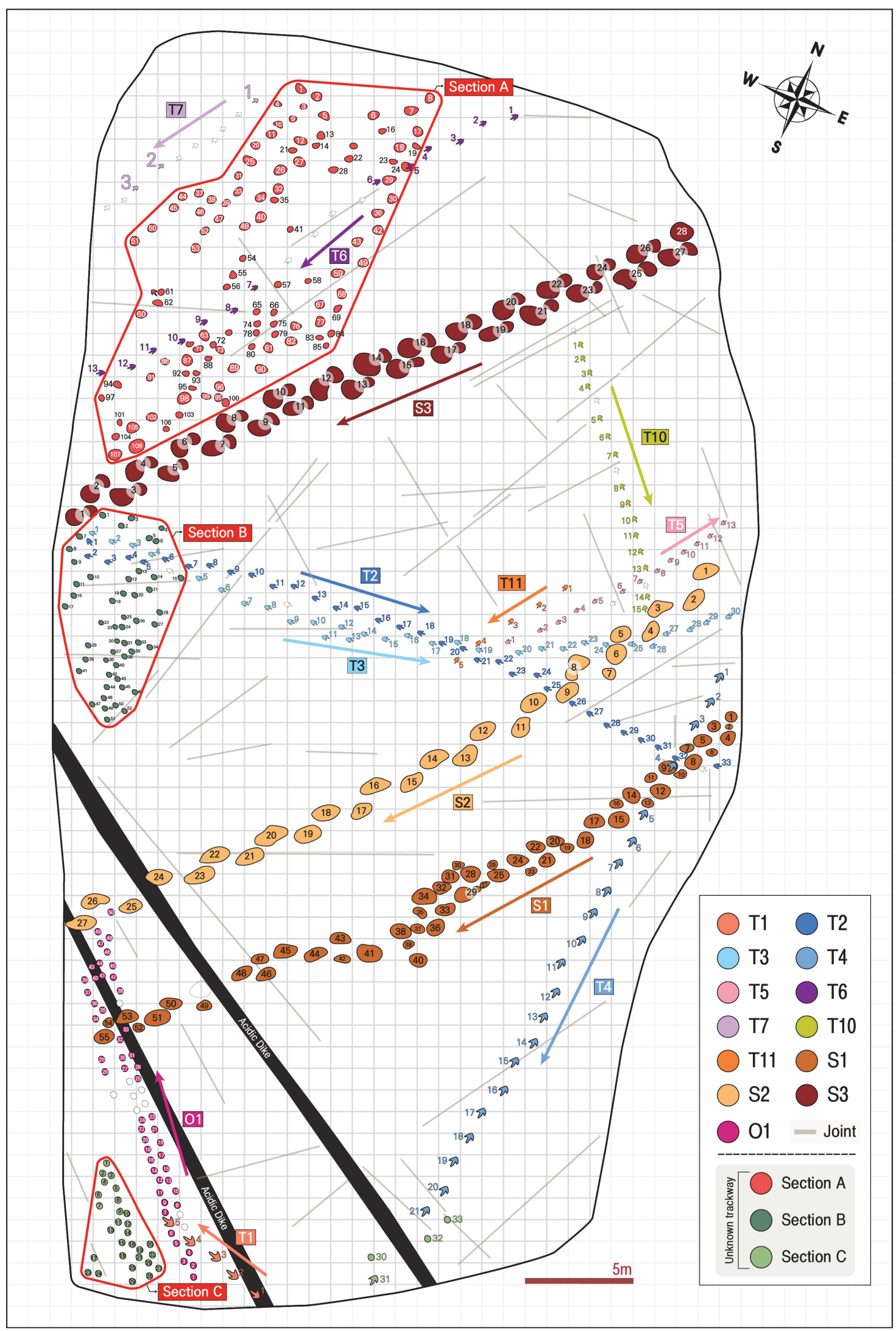

Fig. 3. Schematic map showing dinosaur footprints and track site in the study area. $\mathrm{T}$; theropod trackways, $\mathrm{S}$; sauropod trackways, O; ornithopod trackway. 
Table 1. Locations of ground control points (GCPs) and survey results of the Sinseongri dinosaur track site. The coordinates were measured at each point using GNSS

\begin{tabular}{|c|c|c|c|c|}
\hline Measuring Point & GCPs & $\mathrm{X}(\mathrm{m})$ & $\mathrm{Y}(\mathrm{m})$ & Altitude $(\mathrm{m})$ \\
\hline & $\mathrm{CP} 1$ & 414721.649 & 198582.785 & 336.524 \\
\hline & $\mathrm{CP} 2$ & 414691.547 & 198609.954 & 317.184 \\
\hline & $\mathrm{CP} 3$ & 414681.891 & 198620.039 & 309.347 \\
\hline & $\mathrm{CP} 4$ & 414674.807 & 198608.200 & 307.918 \\
\hline & $\mathrm{CP} 5$ & 414668.177 & 198597.961 & 306.569 \\
\hline
\end{tabular}

이러한 표면오염물의 특성을 규명하기 위해서 휴대용 실 체현미경(Dino-Lite, AD7013MZT)과 P-XRF(Oxford, XMET7500)를 이용하여 기재적 특징을 분석하였. 또한 P$\mathrm{XRF}$ 의 한계를 보완하고 검출한 데이터의 교차검증을 위 해 화석지 표면에서 탈락한 미세시편을 수습하여 에너지 분산형분광기(EDS)를 장착한 주사전자현미경(SEM)을 활 용해 미세조직 관찰과 화학조성을 검출하였다. 이때 사 용한 기기는 TESCAN사의 MIRA3이다.

한편 화석지 암석의 표면에 대한 손상도 평가를 위해 현장에서 손상유형을 기록하였으며, 이를 바탕으로 손상 지도를 작성하고 정량적인 손상률을 산출하였다. 또한 화 석지 암석의 물성과 풍화도를 산출하기 위해 Proceq사의 Pundit Lab 기기를 통해 초음파 측정을 실시하였으며, Proceq의 Rock Schmidt를 이용하여 암석의 반발경도를 함께 측정하였다. 측정한 초음파 속도분포는 화석의 실 측도면에 투영하여 2D 모델링하였으며, 반발경도와의 비 교를 통해 강도를 해석하였다.

\section{3. 결과 및 해석}

\section{1. 암석 및 광물학적 특성}

신성리 공룡발자국 화석의 모암은 전반적으로 강한 열 변질을 받아 혼펠스화되어 있으나 사암과 이암 및 미사 암 등의 암상을 보인다. 미세조직을 검토하기 위해 화석 지의 연장선에 노출되어 있는 동일 지층의 단면에서 분 석용 시료를 수습하였다. 이들의 실체현미경 관찰 결과, 전체적인 암상은 미사암과 이암으로 확인되었다.

미사암은 엽층 또는 박층을 이루며 반복적으로 교호하 는 암상으로 연록색 내지 암록색 또는 청회색의 암색을 보인다. 상대적으로 조립질인 세립질 사암과 미사암 및 이암의 경계는 점이적이고 이암과 사암 또는 미사암의 경계는 뚜렷하다(Kim et al., 2019). 사질층은 아장석 사
암질이며 부분적으로 화산암 기원의 반자형 석영립이 산 재한다(Fig. 4A). 이암은 청회색 및 담갈색 기질부를 바 탕으로 미립의 점토입자들로 구성되며 뚜렷한 엽리가 평 행하게 배열되어 발달한다. 또한 미립질 점토와 함께 청 회색 내지 담회색이 교호하는 수 $\mathrm{mm}$ 의 엽층리가 관찰된 다(Fig. 4B).

동일 암석의 편광현미경 관찰 결과, 미사암과 이암에 서는 공통적으로 석영, 사장석, 흑운모, 녹니석, 방해석, 점토광물 및 불투명광물이 관찰되며 석영과 사장석 및 점토광물의 함량이 우세하다. 시료와 박편에서 층리가 관 찰되는데 전체적으로 사질의 함량이 우세한 부분과 이질 이 우세한 부분이 호층을 이루며 교호한다. 박편에서 관 찰되는 어두운 부분은 대부분 점토광물과 기질로 확인되 며 부분적으로 석영과 사장석이 $0.2 \mathrm{~mm}$ 의 크기를 보인다. 이차광물로 백운모와 방해석이 관찰되며 변질광물로 소 량의 녹니석이 산재한다(Fig. 4A).

이암은 대부분 미립 내지 은미정질 결정들로 이루어져 있으나 부분적으로 $0.3 \mathrm{~mm}$ 내외의 결정들이 관찰된다. 세 립의 결정은 주로 석영과 사장석으로 이루어져 있으며 점토광물과 기질은 박편에서 어둡게 관찰된다. 이차광물 로 미립의 백운모가 관찰되며 변질광물인 녹니석이 산점 상으로 분포한다(Fig. 4B).

화석지 구성암석의 광물조성을 검출하기 위해 동일 시 료를 분말화하여 X-선 회절분석을 실시하였다. 이 결과, 미사암과 이암 모두 흑운모, 알칼리 장석, 사장석, 석영, 휘석 및 각섬석이 공통적으로 확인되며 미사암에서는 녹 니석이 동정되었다(Fig. $4 \mathrm{C}, 4 \mathrm{D})$. 전반적으로 미사암과 이암에서 확인되는 석영의 회절강도는 유사하나, 그 외 의 조암광물에서는 상이하게 나타난다. 따라서 두 암석 의 광물조성은 유사하나 함량은 다소 상이한 것으로 판 단된다.

미사암과 이암에서 검출되는 휘석과 각섬석은 심성암 

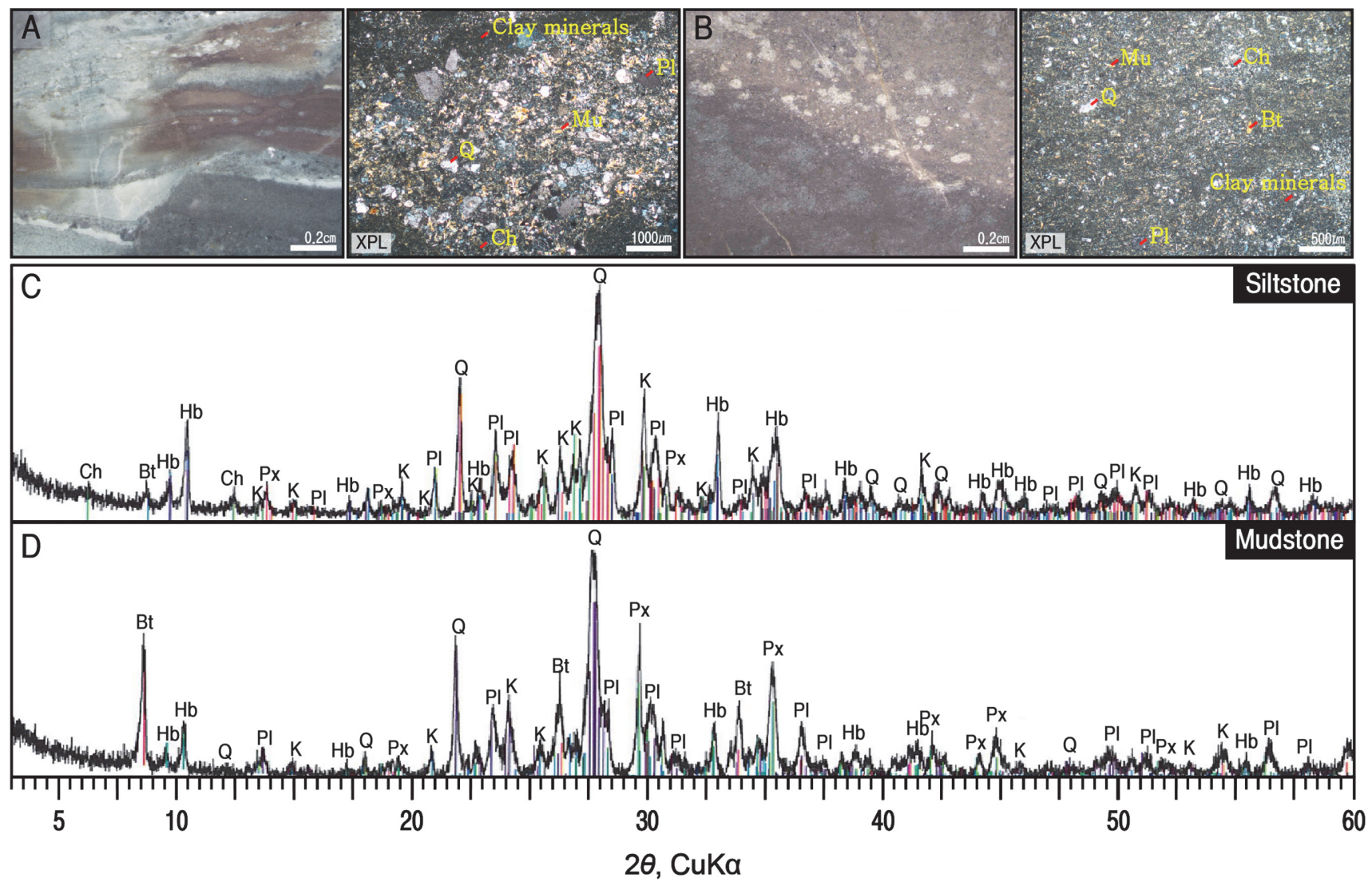

Fig. 4. Lithological photographs, polarizing microscopic images, and X-ray powder diffraction patterns for host rock of dinosaur track site in the study area. (A) Occurrence of siltstone. (B) Occurrence of mudstone. (C, D) X-ray powder diffraction patterns. Bt; biotite, $\mathrm{Ch}$; chlorite, $\mathrm{Hb}$; amphibole, Px; pyroxene, Q; quartz, Pl; plagioclase, K; alkali feldspar.

류의 관입에 따라 접촉변성을 야기하는 혼펠스화 과정에 서 생성된 열변질 광물로서, 부분적으로 함유된 석회질 광물의 반응에 영향을 받은 것으로 판단된다. 또한 녹니 석과 운모 등 팽윤성 점토광물의 경우, 자연환경에서 접 촉하는 수분의 건조와 습윤과정에서 암석 내부에 응력이 형성되어 이차적인 풍화를 발생시키므로 화석지 보존에 문제점으로 작용할 수 있다.

\section{2. 손상특성 및 평가}

암석의 물리적 풍화는 구조적 불안을 초래하는 가장 큰 요인으로 이로 인해 암석이 손상될 경우 원형이 소실되 어 다른 풍화양상에 의한 손상보다 회복이 어렵다. 따라 서 풍화가 심화된 부분에 대한 즉각적인 보존처리가 요 구되며 풍화의 유발원인을 규명하여 진행속도를 늦출 수 있는 방안을 마련해야 한다. 연구대상 화석지에서는 주 로 미세균열과 함께 다양한 방향의 절리계가 확인되며, 이를 따라 박락과 탈락 등이 나타난다.

화석지 남쪽에는 중성 내지 염기성 맥암이 주향 $\mathrm{N} 62^{\circ} \mathrm{W}$ 에 $\mathrm{N} 81^{\circ} \mathrm{W}$ 의 경사를 가지며 관입해 있다(Fig. 3). 층상퇴
적암에 발달하는 절리는 일반적으로 층리면에 수직이고 인접한 절리와 평행한 배향과 규칙적인 간격을 가지며 절리조를 이룬다. 신성리 화석지에는 다수의 불연속면이 나타나며 절리는 발자국에 구조적인 영향을 미칠 수 있 다(Fig. $5 \mathrm{~A}, 5 \mathrm{~B}$ ).

암반에는 절리 및 균열 등과 같은 다양한 임의의 불연 속면이 다른 불연속면과 교차하여 나타나므로 이를 정확 히 구분하기는 어려움이 있다. 따라서 절리군의 방향성 을 고려하여 기록하였으며 불규칙 절리는 미세균열로 세 분하였다. 박리상 균열은 발자국 화석에서 비교적 심하 게 풍화된 부위에서 부분적으로 확인된다(Fig. $5 \mathrm{C}, 5 \mathrm{D}$ ). 또한 박리가 지속적으로 발달하면서 화석이 보존된 층리 면이 박락되어 하부의 퇴적층이 드러난 경우도 흔하다 (Fig. 5E, 5F).

신성리 화석지에서 산출되는 공룡발자국을 대상으로 물리적 손상지도를 작성하고 Jo and Lee(2011)의 방법에 따라 각 보행렬의 발자국에 대한 균열지수 및 손상도를 산출하였다(Table 2). 연구대상 화석지의 전체적인 손상 양상을 살펴보면 미세균열과 박락을 제외하면 다른 손상 

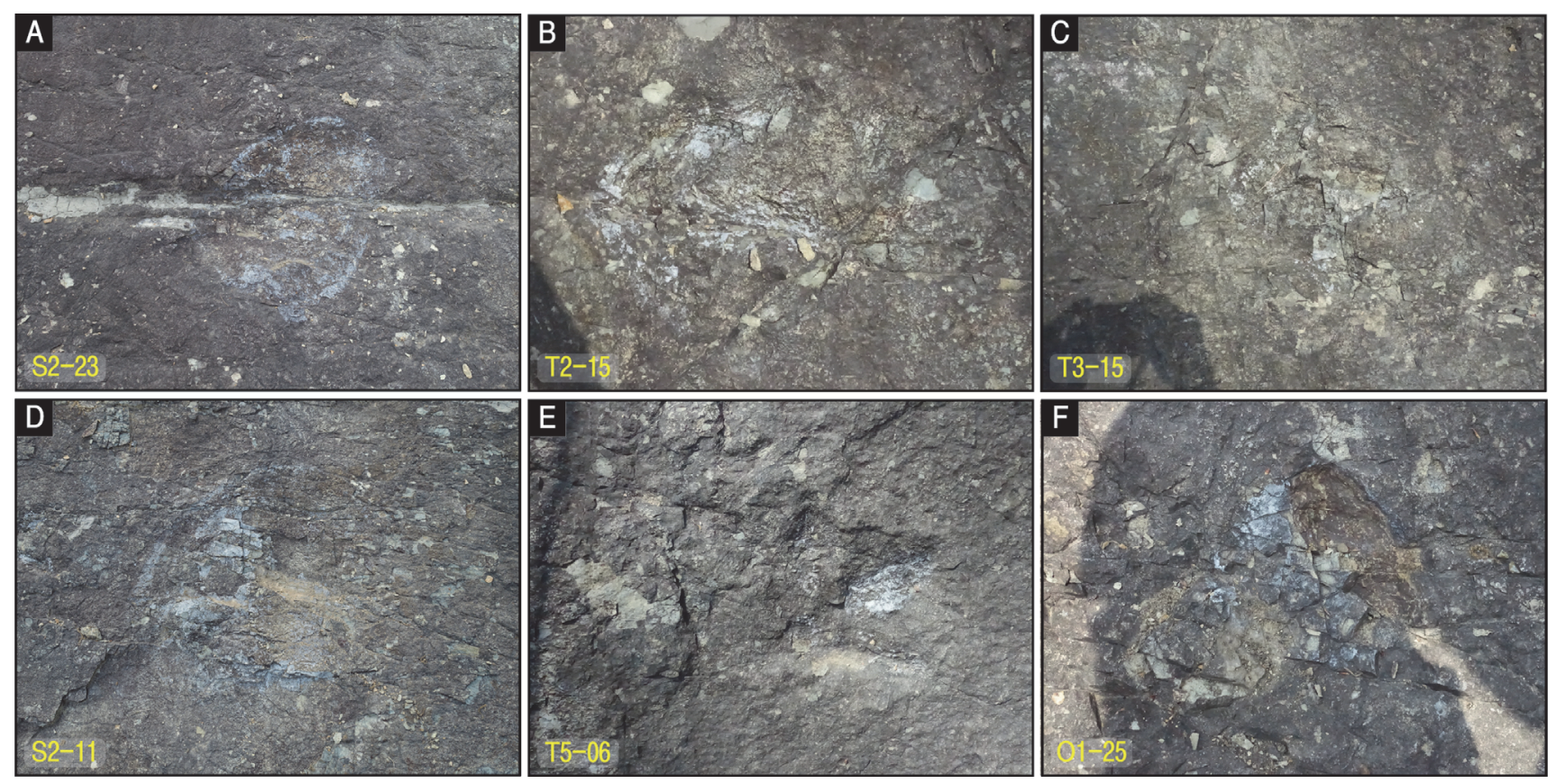

Fig. 5. Representative physical weathering states of dinosaur track site in the study area. Occurrences of joints (A, B), various blistering, and exfoliation ( $\mathrm{C}$ to $\mathrm{F}$ ) on each footprint fossils.

Table 2. Summary on the dinosaur trackways and quantitative deterioration assessment of the study area

\begin{tabular}{|c|c|c|c|c|c|c|c|c|}
\hline \multirow{2}{*}{ Types } & \multirow{2}{*}{$\begin{array}{l}\text { Track } \\
\text { ways }\end{array}$} & \multirow{2}{*}{$\begin{array}{c}\text { No. of } \\
\text { Footprints }\end{array}$} & \multicolumn{3}{|c|}{ Crack Index (CI) } & \multicolumn{3}{|c|}{ Exfoliation (\%) } \\
\hline & & & Min & Max & Mean & Min & Max & Mean \\
\hline \multirow{3}{*}{ Sauropod } & $\mathrm{S} 1$ & 55 & 0.80 & 4.10 & 2.09 & - & 5.00 & 0.87 \\
\hline & $\mathrm{S} 2$ & 27 & - & 4.50 & 1.38 & - & 5.80 & 1.58 \\
\hline & S3 & 28 & - & 5.30 & 2.66 & - & 4.40 & 0.80 \\
\hline \multirow{7}{*}{ Theropod } & $\mathrm{T} 1$ & 5 & 1.10 & 3.50 & 2.46 & - & - & - \\
\hline & $\mathrm{T} 2$ & 33 & 0.40 & 6.10 & 2.28 & - & 13.00 & 2.49 \\
\hline & T3 & 19 & 1.60 & 6.30 & 3.03 & 0.70 & 18.20 & 7.83 \\
\hline & $\mathrm{T} 4$ & 21 & 2.40 & 8.80 & 5.33 & 2.60 & 18.90 & 8.26 \\
\hline & $\mathrm{T} 5$ & 13 & 2.50 & 7.90 & 5.22 & - & 27.80 & 12.73 \\
\hline & T6 & 13 & 4.00 & 8.20 & 5.56 & - & 12.10 & 5.24 \\
\hline & $\mathrm{T} 10$ & 15 & 1.90 & 5.40 & 3.42 & 1.50 & 17.20 & 6.91 \\
\hline Ornithopod & $\mathrm{O} 1$ & 33 & 0.60 & 7.10 & 4.65 & 2.40 & 35.30 & 9.70 \\
\hline
\end{tabular}

유형은 거의 나타나지 않는다. 따라서 이 연구에서는 미 세균열과 박락에 대해서만 각 보행렬과 발자국의 종류별 균열지수와 손상률을 그래프로 도시하였다(Fig. 6).

물리적 손상유형에 대한 균열지수(CI) 및 손상률(\%)을 산출한 결과, 발자국의 면적에 비하여 박락이 가장 높은 점유율을 보였다. 또한 균열지수에서 미세균열이 매우 우 세한 손상요인으로 확인된다. 일부 발자국에서 박리상 균 열이 발달하나 모두 0.3 이하로 구조적 문제는 크지 않 을 것으로 판단된다. 용각류 1 번 보행렬의 12 번째 발자 국에서는 유일하게 구조상균열(0.2)이 나타난다. 이 때문
에 발생한 탈락편은 반드시 보존처리를 수행하여 유실을 방지해야 할 것이다.

한편 공룡발자국의 미세균열에 대한 균열지수 그래프 작성 결과, 전체 보행렬 중에서 수각류에 대한 균열지수 는 산포도가 높고 다소 큰 차이가 있다(Fig. 6A). 이 중 에서 $\mathrm{T} 4, \mathrm{~T} 5, \mathrm{O} 1$ 보행렬이 가장 높고 다양하게 나타난다. 반면 용각류는 균열지수가 낮고 좁은 범위에서 확인되며 $\mathrm{S} 2$ 의 손상이 평균 2.8(1.0 5.3)로 가장 적다.

박락은 조각류에서 광범위하게 나타나고 보행렬 중 25 번째 발자국에서 보이는 박락이 가장 높은 손상률(35.3\%) 

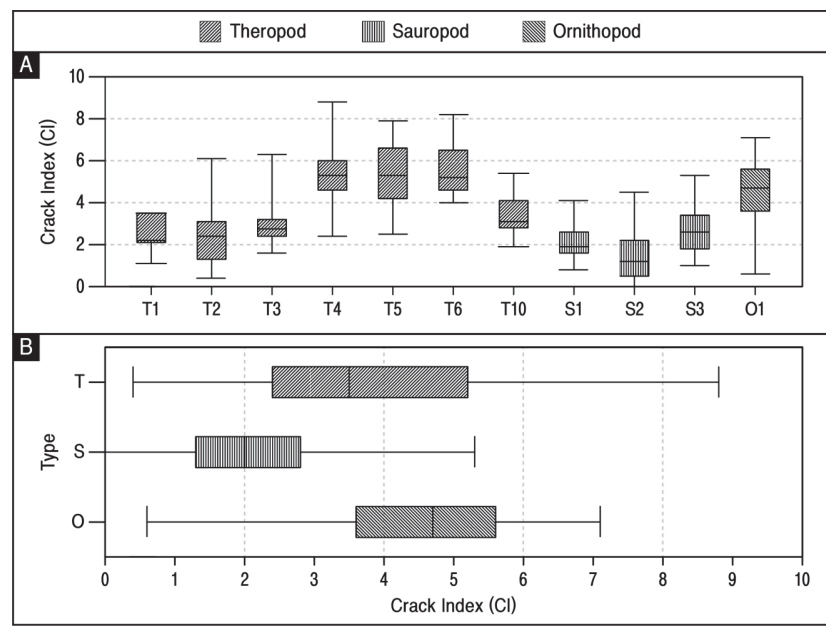

Fig. 6. Diagrams showing the crack index $(\mathrm{CI})$ and quantitative deterioration rate of dinosaur track site in the study area. (A) Crack index for micro cracks. (B) Deterioration rate for exfoliations.

을 보이며 박리(1.6)도 일부 확인된다. 수각류는 5 번 보 행렬의 8 번 발자국에서 박락(27.8\%)이 가장 높게 산출되 었다. 용각류는 넓은 발자국의 면적 대비 박락에 의한 손 상률은 상대적으로 적었다(Fig. 6B).

연구대상 공룡발자국은 대부분 형상이 남아있으나 보 존상태가 불량한 화석은 발자국의 형태가 불분명하다. 따 라서 손상이 가속화되어 완전소실이 발생하지 않도록 관 리가 필요하다. 외곽선이 남아있는 발자국 중에는 발자
국 면적의 절반 이상에서 손상이 나타나는 것은 거의 확 인되지 않는다. 또한 미세균열을 제외한 모든 손상요인 에서 매우 낮은 점유율을 보이므로 현재 신성리 공룡발 자국 화석지는 전체적으로 풍화도가 낮으며 비교적 안정 적인 것으로 판단할 수 있다.

\section{3. 표면오염물 분석}

연구대상 화석지는 발굴과 정비 및 장시간 노출의 영 향으로 다양한 손상양상이 나타난다. 이에 따른 표면오 염물의 풍화특성을 파악하고 발생원소를 규명하기 위해 비교적 신선한 부분과 비교분석하였다. 우선 화석지의 표 면오염물을 분석하기 위해 육안으로 오염물의 산출상태 를 정밀 관찰하고, 색과 오염도에 따라 대표적인 변색부 위를 선정하였다.

이 결과, 화석지 층준의 신선부 표면은 암회색으로 확 인되며(Fig. 7A), 전반적으로 암석의 기질은 미정질로 육 안관찰을 통해 조암광물의 식별이 어렵다. 흑색오염물은 발자국화석의 표면에서 유색광물 등이 관찰되는 경우와 오염물의 침착에 따라 다른 부위에 비해 흑색도가 높은 미립자의 석출이 확인되었다(Fig. $7 \mathrm{~B}$ ).

현재 화석지에서 확인되는 공룡발자국은 박락 등의 물 리적 풍화와 함께 화학적 풍화도 진행된 상태이다. 따라 서 회청색에서 회색을 띠는 원암과 달리 황색과 갈색으 로 일부 변색된 지점이 나타난다. 황색 및 갈색오염물은
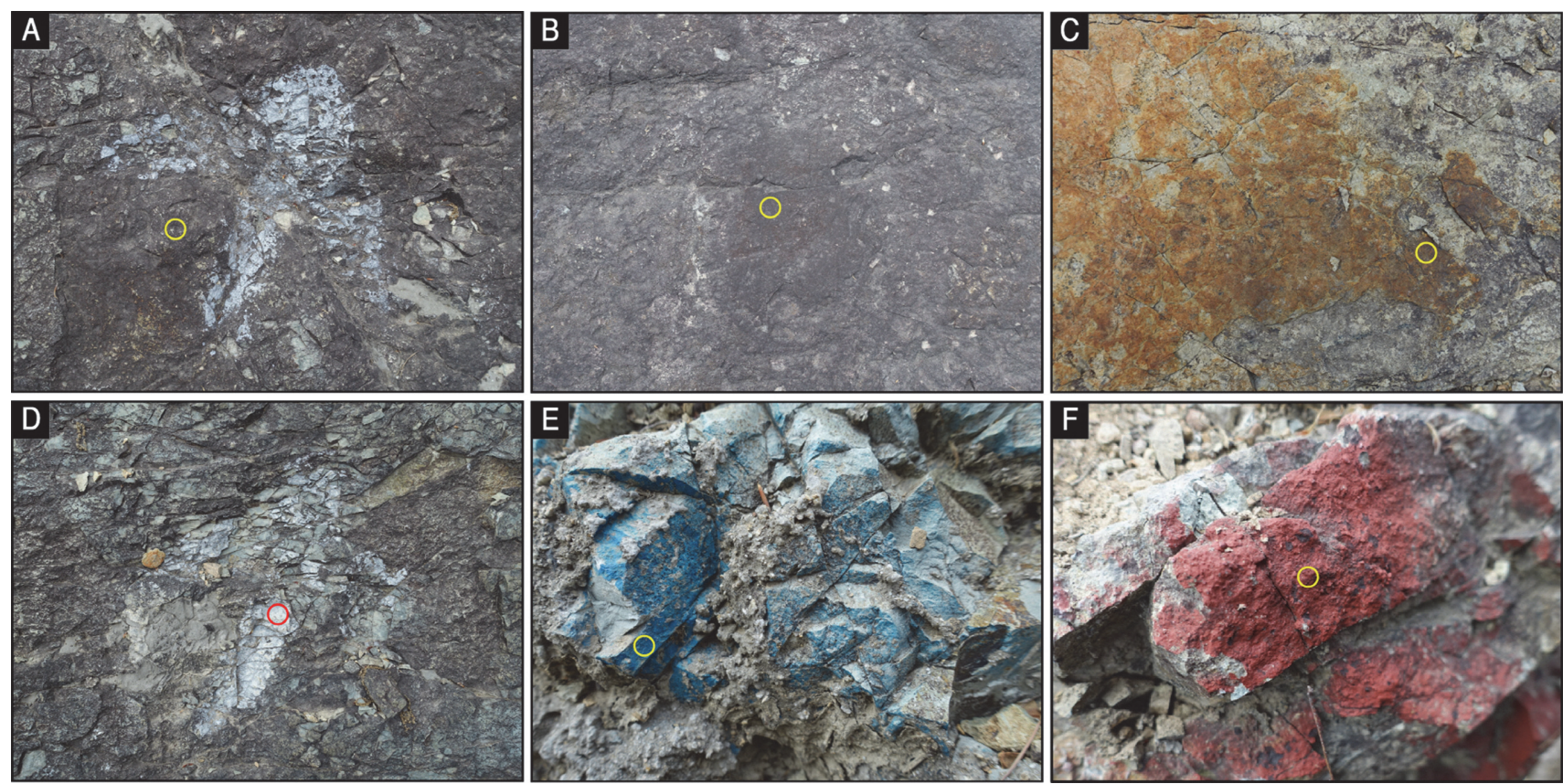

Fig. 7. Detail P-XRF measuring points for fresh part and surface contaminations of dinosaur track site in the study area. (A) Fresh parts. (B) Black contaminants. (C) Brown contaminants. (D) White paint. (E) Blue paint. (F) Red paint. The yellow circles in the figures are the P-XRF measurement points. 


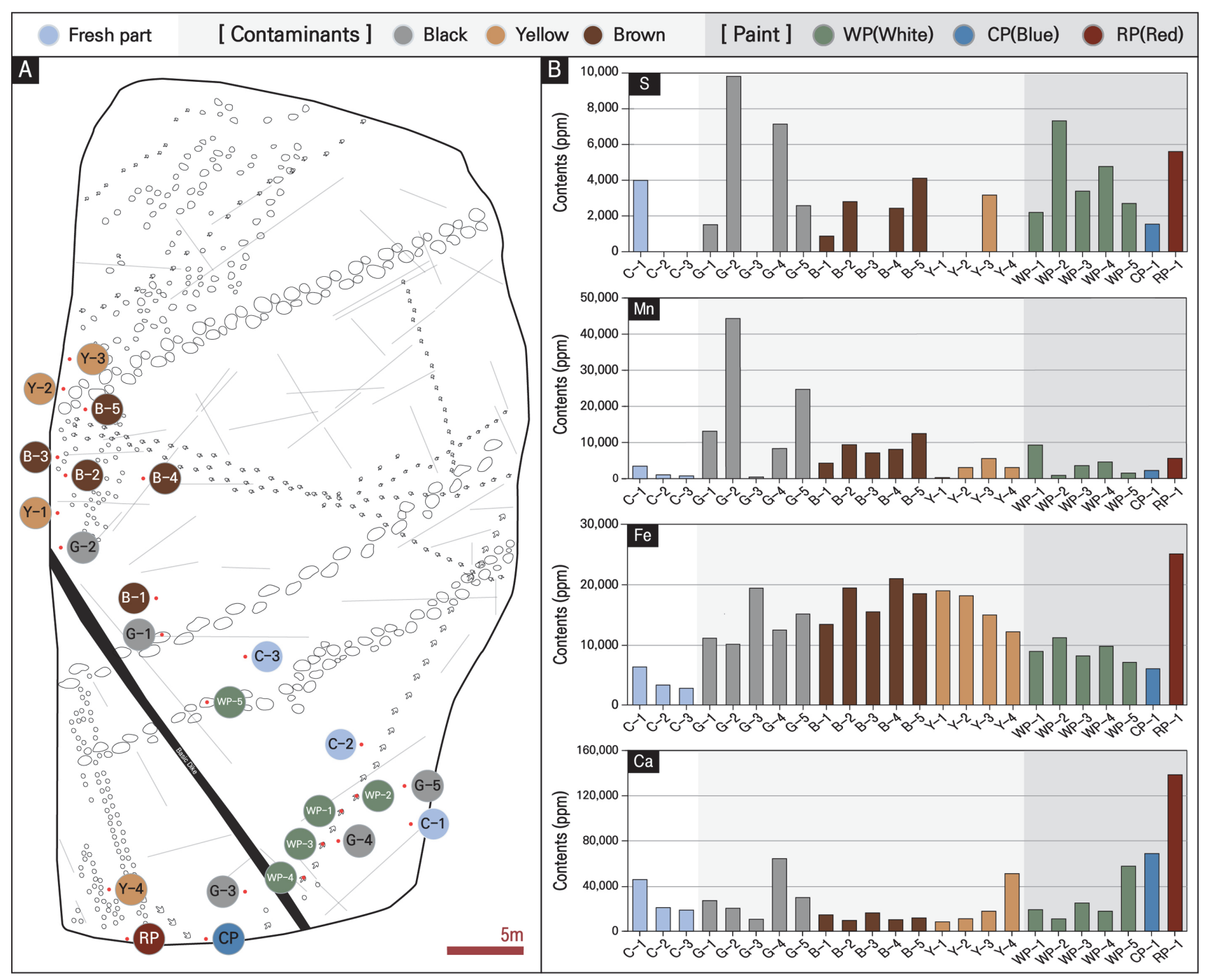

Fig. 8. Measuring points and concentrations in ppm on fresh part and surface contaminations of dinosaur track site in the study area. The numbers are the same as those in Table 3.

흑색 오염부에 비해 화석지의 가장자리에 국부적으로 분 포한다(Fig. 7C). 백색 페인트는 선행 학술조사 당시 공 룡발자국의 형상을 돋보이기 위해 사용하였으며 대부분 의 발자국에 남아있다(Fig. 7D). 또한 연구대상 화석지에 는 부분적으로 청색 및 적색의 페인트 흔이 암석 표면에 단단하게 고착되어 있다(Fig. 7E, 7F).

각각의 표면오염물 중에 총 22지점을 선정하여 P-XRF 분석을 실시하였으며, 분석지점에 대한 정보는 Fig. 8과 같다. 우선 화석지를 구성하는 신선한 지점을 대상으로 분석한 결과, 황 $(\mathrm{S})$, 망간 $(\mathrm{Mn})$, 철 $(\mathrm{Fe})$ 및 칼슘 $(\mathrm{Ca})$ 의 함 량은 극히 미량 검출되거나 검출되지 않는다(Table 3). 그 러나 오염물 피복지점 중에서 흑색, 황색 및 갈색오염물 을 대상으로 분석한 결과, 흑색오염물은 모든 지점에서 신선한 지점에 비해 $\mathrm{S}, \mathrm{Mn}$ 및 $\mathrm{Ca}$ 함량이 비교적 높았다
(Fig. 8B).

특히 G-2의 S(9,800ppm) 및 $\mathrm{Mn}(44,304 \mathrm{ppm})$ 과 G-4의 $\mathrm{Ca}(64,236 \mathrm{ppm})$ 함량은 화석지 오염물 중에서 가장 높게 검출되었다. G-2의 $\mathrm{Mn}$ 은 신선한 부위의 평균값 $(1,764 \mathrm{ppm})$ 에 비해 약 25 배 정도 많은 함량이다. 따라서 망간산화 물이 암석 표면에 고착되면서 흑화현상을 야기한 것으로 판단된다. 또한 신선한 암석에서는 검출되지 않았던 $\mathrm{Sn}(681 \mathrm{ppm})$ 및 $\mathrm{Pb}(194 \mathrm{ppm})$ 과 같은 중금속들이 일부영역 (G-5)에서 검출되었다(Fig. 8B).

동일한 방법으로 갈색오염물을 분석한 결과, 원소의 평 균 함량은 S 2,557ppm, Mn 8,265ppm, Fe 175,495ppm으 로 검출되었다(Table 3). 이를 신선한 부위와 비교하면, $\mathrm{Fe}$ 은 약 4.3 배 정도 높은 함량을 나타냈다. 황색오염물은 갈색오염물과 비슷한 경향을 보였으며 $\mathrm{S}, \mathrm{Mn}, \mathrm{Fe}$ 이 상대 
Table 3. Measurement results (ppm) on the contaminants by P-XRF of dinosaur track site in the study area

\begin{tabular}{|c|c|c|c|c|c|c|c|c|c|c|c|c|c|c|}
\hline \multicolumn{2}{|c|}{ Measuring point } & $\mathrm{Si}$ & $\mathrm{Al}$ & $\mathrm{Fe}$ & $\mathrm{Mn}$ & $\mathrm{Ca}$ & $\mathrm{K}$ & $\mathrm{Ti}$ & $\mathrm{S}$ & $\mathrm{Ba}$ & $\mathrm{Cu}$ & $\mathrm{Zn}$ & $\mathrm{Sn}$ & $\mathrm{Pb}$ \\
\hline \multirow{3}{*}{ Fresh } & $\mathrm{C}-1$ & 171,683 & 80,615 & 63,144 & 3,473 & 45,711 & 7,142 & 7,054 & - & - & - & 292 & - & - \\
\hline & $\mathrm{C}-2$ & 196,065 & 127,564 & 33,006 & 1,054 & 20,808 & - & 114,523 & - & - & 22 & 143 & - & - \\
\hline & $\mathrm{C}-3$ & 145,683 & 83,615 & 27,724 & 766 & 18,615 & - & 90,658 & - & - & - & 109 & - & - \\
\hline \multirow{14}{*}{ Contaminants } & Y-1 & 217,311 & 118,491 & 189,534 & 277 & 8,243 & - & 6,233 & - & - & - & 105 & - & - \\
\hline & $\mathrm{Y}-2$ & 219,536 & 112,563 & 181,378 & 3,041 & 11,008 & - & 11,113 & - & - & - & 370 & - & - \\
\hline & Y-3 & 240,648 & 100,644 & 149,508 & 5,527 & 17,655 & 6,636 & 6,343 & 3,166 & - & - & 261 & - & - \\
\hline & Y-4 & 249,211 & 87,159 & 121,523 & 3,033 & 5,056 & 7,104 & 9,320 & - & - & - & 370 & - & - \\
\hline & G-1 & 241,416 & 102,093 & 110,945 & 13,121 & 27,054 & 12,150 & 10,842 & 7,311 & - & - & 510 & - & - \\
\hline & G-2 & 231,588 & 108,456 & 100,888 & 44,304 & 20,289 & 10,090 & 6,266 & 1,515 & - & - & 192 & - & - \\
\hline & G-3 & 205,065 & 127,564 & 193,861 & 448 & 10,525 & - & 5,836 & - & - & - & 167 & - & - \\
\hline & G-4 & 230,277 & 81,297 & 124,467 & 8,321 & 64,236 & 14,710 & 9,500 & 9,800 & - & - & 660 & - & - \\
\hline & G-5 & 230,367 & 77,161 & 151,042 & 24,695 & 29,733 & 11,569 & 8,396 & 7,129 & - & - & 538 & 681 & 194 \\
\hline & B-1 & 243,020 & 108,468 & 133,801 & 4,277 & 14,441 & 7,074 & 10,556 & 2,579 & - & - & 489 & - & - \\
\hline & B-2 & 216,834 & 99,341 & 194,267 & 9,384 & 9,553 & 5,818 & 6,121 & 872 & 3,533 & - & 255 & - & - \\
\hline & B-3 & 240,779 & 91,855 & 154,688 & 7,106 & 16,220 & 10,233 & 9,200 & 2,798 & - & - & 284 & - & - \\
\hline & B-4 & 209,746 & 97,015 & 209,750 & 8,092 & 10,164 & 5,447 & 6,484 & 2,428 & 3,673 & - & 338 & - & - \\
\hline & B-5 & 217,165 & 96,312 & 184,969 & 12,467 & 11,798 & 7,606 & 7,994 & 4,107 & 3,739 & - & 291 & - & - \\
\hline \multirow{7}{*}{ Paints } & $\mathrm{RP}$ & 134,498 & 61,935 & 250,863 & 5,592 & 138,490 & 5,308 & 5,836 & 5,602 & - & - & 736 & - & - \\
\hline & $\mathrm{CP}$ & 267,902 & 87,414 & 60,165 & 2,213 & 68,748 & 18,559 & 8,757 & 1,541 & - & - & 241 & - & 347 \\
\hline & WP-1 & 257,911 & 105,717 & 97,479 & 9,260 & 19,094 & 15,164 & 6,781 & 3,986 & - & - & 388 & - & - \\
\hline & WP-2 & 162,932 & 87,517 & 70,764 & 876 & 10,896 & 5,124 & 192,222 & 2,195 & - & - & 380 & 516 & - \\
\hline & WP-3 & 181,683 & 83,615 & 89,065 & 3,573 & 2,429 & 12,333 & 140,144 & 3,384 & - & - & 361 & - & - \\
\hline & WP-4 & 23,821 & 98,371 & 111,813 & 4,566 & 17,657 & 9,262 & 82,726 & 4,765 & - & - & 475 & - & - \\
\hline & WP-5 & 175,660 & 94,235 & 81,518 & 1,510 & 57,567 & 7,047 & 119,320 & 2,702 & - & - & 285 & - & - \\
\hline \multicolumn{2}{|l|}{ Average } & 190,724 & 84,468 & 128,590 & 7,374 & 30,183 & 7,432 & 36,759 & 2,745 & 456 & 1 & 343 & 50 & 23 \\
\hline
\end{tabular}

C; fresh parts, Y; yellow, G; black, B; brown, RP; red paint, CP; blue paint, WP; white paint

적으로 낮은 함량을 보인다. 황색과 갈색오염물은 비정 질의 철산화물이 침착되었기 때문이며, $\mathrm{Ca}$ 과 $\mathrm{S}$ 이 동시에 나타나는 지점은 석고와 같은 황산염광물이 생성되었을 것으로 판단된다(Fig. 8B).

이 화석지에 산재하는 페인트 오염물의 P-XRF 분석 결과, $\mathrm{Fe}, \mathrm{Ca}, \mathrm{Ti}$ 등의 발색원소가 공통적으로 검출된다. 백색 페인트에서는 Ti이 6,781 192,222(평균 108,239)ppm 으로 특징적으로 높게 나타난다(Table 3). 청색 페인트 피 복부에서는 청색의 발색원소인 $\mathrm{Co}$ 와 $\mathrm{Cu}$ 가 검출되지는 않았으나 $\mathrm{Fe}$ 이 $60,165 \mathrm{ppm}$ 검출되는 것으로 보아 페로시 안화 철의 수화물인 프러시안 블루 $\left(\mathrm{Fe}_{4}\left(\mathrm{Fe}(\mathrm{CN})_{6}\right)_{2}\right)$ 가 첨 가된 페인트로 해석할 수 있다. 적색 페인트는 발색원소 인 $\mathrm{Hg}, \mathrm{Pb}, \mathrm{Cd}$ 등은 검출되지 않았으나 백색과 청색에 비해 $\mathrm{Fe}(250,863 \mathrm{ppm})$ 과 $\mathrm{Ca}(138,490 \mathrm{ppm})$ 함량이 상대적 으로 높았다(Fig. 8B).

한편 화석지 암석의 풍화정도와 변질상태를 파악하고, 표면오염물의 미세조직과 성분을 분석하기 위해 극미량
의 오염물 시료를 이용하여 주사전자현미경 관찰과 에너 지분산형 X-선 분석을 수행하였다. 이 결과, 오염물 시료 에서 주로 미세한 조암광물 입자들이 관찰되었으며 부분 적으로 유기물이 함께 공존하는 것을 볼 수 있다.

황색오염물은 전반적으로 높은 기공을 포함한 성긴 미 세조직을 가지며, 매우 약한 물성을 나타낸다. 특히 2번 지점은 $\mathrm{Fe}$ 과 $\mathrm{Mg}$ 함량을 통해 판상의 흑운모임을 알 수 있다(Fig. 9A, 9B). 갈색오염물은 주로 풍화산물로 추정 되는 망간산화물이다. $\mathrm{Mn}$ 의 함량은 5 번과 6 번 지점에서 각각 31.60 및 $35.53 \mathrm{wt} \%$ 가 검출되었다(Table 4). 이는 운 모와 장석의 풍화과정에서 망간이 유리되어 수산화망간 을 형성하면서 변색을 야기한 것으로 해석할 수 있다 (Fig. 9C, 9D).

백색 페인트는 7번(48.52wt\%) 및 8번(35.78wt\%)과 같 이 높은 $\mathrm{Ti}$ 함량을 갖는 것으로 보아 이산화티타늄 $\left(\mathrm{TiO}_{2}\right)$ 을 안료로 사용한 페인트임을 알 수 있다(Fig. 9E, 9F). 이 페인트는 물리화학적으로 매우 안정된 물질이며 백색 

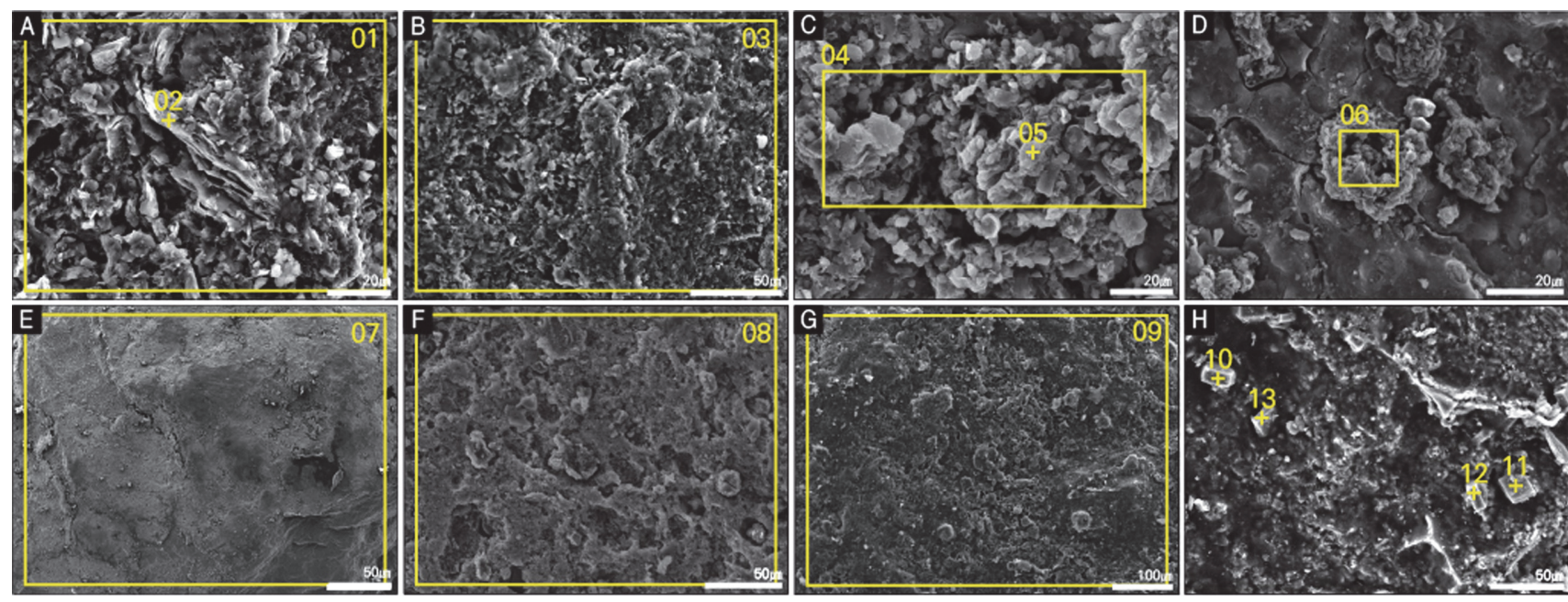

Fig. 9. Microphotographs showing the representative scanning electron microscope (SEM) and energy dispersive spectroscopy (EDS) for surface contaminations analysis of dinosaur track site in the study area. (A, B) Yellow contaminants. (C, D) Brown contaminants. (E, F) White paint. (G) Red paint. (H) Blue paint.

Table 4. Results on contaminants by SEM-EDS analysis of dinosaur track site in the study area

\begin{tabular}{|c|c|c|c|c|c|c|c|c|c|c|c|c|}
\hline \multirow{2}{*}{\multicolumn{3}{|c|}{ Measuring point }} & \multicolumn{10}{|c|}{ Oxide Concentration (wt.\%) } \\
\hline & & & $\mathrm{SiO}_{2}$ & $\mathrm{Al}_{2} \mathrm{O}_{3}$ & $\mathrm{Fe}_{2} \mathrm{O}_{3}$ & $\mathrm{MnO}$ & $\mathrm{CaO}$ & $\mathrm{MgO}$ & $\mathrm{Na}_{2} \mathrm{O}$ & $\mathrm{K}_{2} \mathrm{O}$ & $\mathrm{TiO}_{2}$ & $\mathrm{C}$ \\
\hline \multirow{6}{*}{ Contaminants } & \multirow{3}{*}{ Y } & 1 & 38.11 & 17.37 & 24.38 & - & 0.95 & 5.77 & 4.19 & - & - & 9.24 \\
\hline & & 2 & 37.11 & 16.38 & 31.82 & - & 1.15 & 2.87 & 1.98 & - & 1.13 & 7.56 \\
\hline & & 3 & 38.19 & 14.53 & 43.57 & - & - & 2.89 & 1.98 & 0.82 & - & - \\
\hline & \multirow{3}{*}{ B } & 4 & 52.12 & 11.23 & 11.25 & 12.16 & 0.60 & 0.64 & - & 1.08 & - & 10.93 \\
\hline & & 5 & 28.32 & 10.99 & 9.79 & 31.60 & 1.77 & 1.40 & - & 0.89 & - & 15.24 \\
\hline & & 6 & 25.90 & 14.29 & 7.22 & 35.53 & 1.09 & 1.78 & - & 1.99 & - & 12.21 \\
\hline \multirow{7}{*}{ Paints } & \multirow{2}{*}{ WP } & 7 & 18.92 & 11.15 & 2.91 & - & - & 4.40 & - & 0.85 & 48.52 & 14.10 \\
\hline & & 8 & 18.86 & 10.47 & 6.87 & - & - & 2.96 & - & - & 35.78 & 25.06 \\
\hline & $\mathrm{RP}$ & 9 & 14.88 & 6.37 & 47.29 & - & 5.56 & 5.68 & 0.69 & 0.27 & 27.29 & 29.28 \\
\hline & \multirow{4}{*}{$\mathrm{CP}$} & 10 & 31.13 & 19.81 & 3.02 & - & 36.17 & - & - & - & - & 9.87 \\
\hline & & 11 & 37.20 & 24.43 & 0.45 & - & 27.03 & - & - & - & - & 10.90 \\
\hline & & 12 & 31.32 & 19.36 & 3.11 & - & 35.78 & - & - & - & - & 10.42 \\
\hline & & 13 & 35.75 & 22.35 & 2.11 & - & 26.86 & - & - & - & - & 12.93 \\
\hline
\end{tabular}

Location of each measuring numbers are presented on the Figure 9.

안료 중 최고 높은 굴절률과 정확한 입도 및 분산성을 가지고 있어 착색력이 우수하다. 반면 페인트의 강한 착 색력은 화석지에 경화된 상태에서 암석의 공극에 침투하 여 제거하기 매우 힘들다. 이는 발자국화석의 보존적 측 면에서 문제가 될 수 있다.

적색 페인트는 $\mathrm{Fe}$ 이 $47.29 \mathrm{wt} \%$ 로 가장 높게 나타나며 무기염료 착색제 중 산화제 2 철 $\left(\mathrm{Fe}_{2} \mathrm{O}_{3}\right)$ 을 주성분으로 하 는 적색의 산화철인 것으로 판단된다(Fig. $9 \mathrm{G})$. 청색 페 인트 분석 결과, 평균 입경이 약 $10 \sim 20 \mu \mathrm{m}$ 를 가지는 능 면체의 방해석 $\left(\mathrm{CaCO}_{3}\right)$ 결정이 관찰된다(Fig. $\left.9 \mathrm{H}\right)$. 이 결
정의 $\mathrm{EDS}$ 분석 결과, $\mathrm{CaO}$ 가 $26.86 \sim 36.17 \mathrm{wt} \%$ 범위를 나 타낸다(Table 4). 이는 도료, 플라스틱, 고무, 제지 등의 정밀화학 산업에 이용되는 초미립 분말로 $1 \mu \mathrm{m}$ 이하의 침강성 탄산칼슘으로 판단된다.

\section{4. 물성평가 및 강도분석}

암석이 풍화되어 공학적 성질이 변하면 그에 따른 초 음파속도에 차이가 나타나므로, 이를 통해 암석이 원래 의 물성에서 얼마나 약화되었는지를 평가할 수 있다. 석 조문화재의 초음파 측정에 가장 적합한 것으로 판단되는 


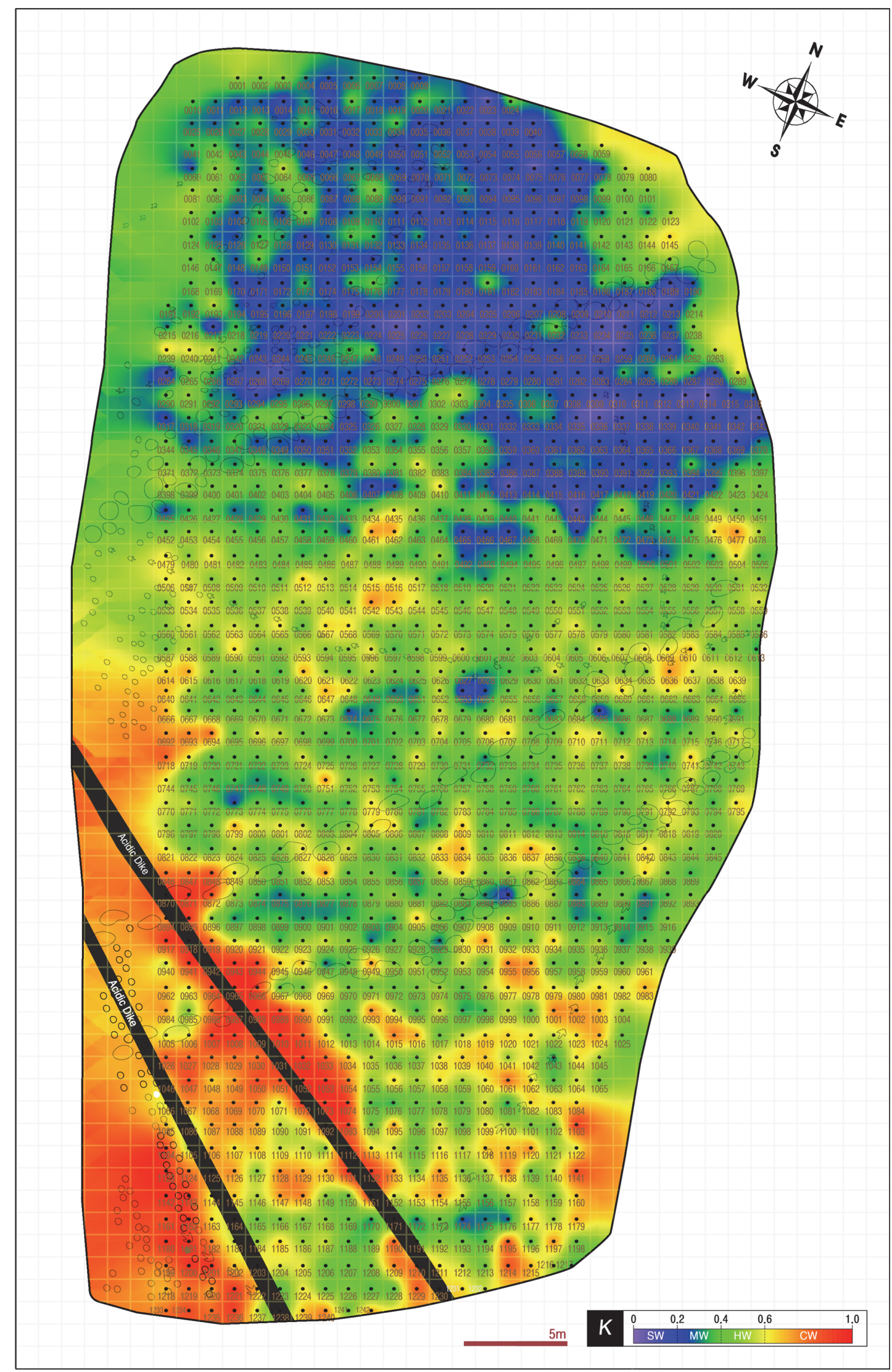

Fig. 10. Ultrasonic velocity map showing the $2 \mathrm{D}$ contour modeling for dinosaur track site in the study area. 
선행연구(Lee et al., 2009; Jo and Lee, 2014; 2015; Lee and $\mathrm{Jo}$; 2017)에서 제시된 초음파속도 신뢰도 검증시험 결과를 토대로 측정조건을 설정하였으며, 이를 신성리 화 석지의 물성진단에 적용하였다.

연구대상 화석지의 초음파 측정은 화석층의 입면적인 형태에 용이한 간접적 속도전달 방식으로 수행하였다. 탐 촉자 간의 거리는 $20 \mathrm{~cm}$ 로 고정하여 총 1,242 지점을 측 정하였다. 이 과정에서 초음파 속도의 감쇠를 일으키는 균열 및 절리 부분은 최대한 피해 검출하였다. 또한 화 석지의 부분별 풍화정도를 가시적으로 파악하기 위해 초 음파 측정지점의 속도를 풍화도지수로 환산하고 이를 등 고선도로 제시하였다(Fig. 10).

이 결과, 화석지 전체의 초음파 속도는 $710 \sim 5,000 \mathrm{~m} / \mathrm{s}$ 의 넓은 분포를 보였으며 평균 $3,075 \mathrm{~m} / \mathrm{s}$ 로 산출되었다. 상당히 낮은 속도를 보이는 측정지점은 화강암에 비해 공극이 많고 구성광물의 입도와 구성이 다양한 미사암과 이암의 암석학적 특성이 반영된 것으로 판단된다.

이를 Iliev(1966)가 제시한 신선한 암석과 풍화된 암석 의 초음파 속도 변화비율에 기초하여 풍화단계별로 풍화 도지수 $(\mathrm{K})$ 와 등급을 검토하였다. 풍화도지수는 $0 \sim 1.00$ 의 분포를 보였으며 0.14 의 평균값이 산출되었다(Table 5). 전체 화석지의 평균 풍화도지수는 0.14 로 신선한단계(FR) 에 해당하며, 전반적인 모암의 물성은 건전한 것으로 판 단된다.

화석지 암반에는 다양한 불연속면이 산재하며 남쪽에 는 관입한 두 개의 암맥이 연장되어 있다. 암맥에서 측 정한 초음파 속도는 700 750m/s(평균 $723 \mathrm{~m} / \mathrm{s}$ )로 높은 풍 화도를 보인다. 이는 염기성 암맥이 풍화에 약하고 육안 으로는 구별하기 어려울 정도의 세립질 또는 유리질의 기질부가 대부분을 차지하고 있기 때문이기도 하다(Son et al, 2007).

암석의 일축압축강도는 지반구조물의 해석에 이용되는 변수를 결정하기 위해 가장 널리 사용하는 시험방법이다. 이러한 안정성 평가는 연구대상과 같은 자연문화재의 암 반에도 적용이 가능하다. 그러나 연구대상 암반은 천연
기념물로 현장에서 일축압축강도 시험을 수행할 정도의 시료 획득은 불가한 상태이다. 따라서 재료시험으로 획 득할 수 있는 물성치를 반발경도, 초음파전달속도, 탄산 화 깊이측정 등 비파괴 시험을 통해 간접적으로 획득하 게 된다.

이 연구에서는 공룡발자국 화석지의 암반 경사면 상부 에서 수평면 및 수직면을 대상으로 슈미트 해머를 이용 한 반발경도 측정을 수행하였으며, 이 과정에는 종으로 5 열, 횡으로 4 열의 선을 $3 \mathrm{~cm}$ 간격으로 작도하여 직교하 는 지점을 타격하였다. 획득한 데이터는 최고와 최저를 제외한 평균값을 사용하였으며, 타격점의 값이 평균 $\pm 20 \%$ 범위에 해당하지 않는 값은 제외하였다. 일축압축강도를 산출하기 위해 필요한 암석의 단위중량은 암반사면 인근 에 떨어져 나온 동일 암석을 수습하여 측정하였으며 $0.025841 \mathrm{MN} / \mathrm{m}^{3}$ 를 적용하였다.

측정한 반발경도 값으로부터 일축압축강도를 산출하는 추정식은 여러 연구자에 의해 다양한 방법으로 제시되었 다. 국내의 퇴적암에 대한 반발경도를 이용한 압축강도 경험식은 매우 빈약하여 주로 국외의 자료를 활용한다. 신성리 화석산지에서 얻은 반발경도를 일축압축강도로 변환하기 위해 Haramy and De Marco(1986)가 제시한 추 정식을 적용하였다.

슈미트 해머로 측정한 반발경도를 일축압축강도로 산 출한 결과, 공룡발자국 화석층의 기반암 상부면, 경사면 의 수평층 및 수직층에 대한 값은 각각 $41.37 \sim 68.20 \mathrm{Mpa}$, 35.90 75.16Mpa, 50.81 76.16Mpa로 나타났다(Table 5). 이 화석지 암석의 일축압축강도는 경사면 상부층 수직면 에서 가장 넓고 높은 분포를 보인다. 한편 화석층의 기 반암 최상부면은 상대적으로 낮고 좁은 범위를 나타냈다 (Fig. 11A).

앞서 측정한 일축압축강도 추정에 신뢰도 높은 결과를 얻기 위해서는 암반에 대한 초음파속도 측정값과의 상호 비교가 필요하다. 암석의 초음파 속도를 일축압축강도로 변환하는 방법은 선행연구(Moradian and Behnia, 2009; Choi and Baek, 2014)를 통해 암석의 종류와 변수에 따

Table 5. Summary on ultrasonic velocity and uniaxial compressive strength of dinosaur track site in the study area.

\begin{tabular}{|c|c|c|c|c|c|c|}
\hline \multicolumn{3}{|c|}{ Classification } & Mean & Min & Max & SD \\
\hline \multicolumn{3}{|c|}{ Ultrasonic velocity $(\mathrm{m} / \mathrm{s})$} & 3,074 & 710 & 5,000 & 961 \\
\hline \multicolumn{3}{|c|}{ Coefficient of weathering $(k)$} & 0.14 & 0.00 & 1.00 & 0.21 \\
\hline \multicolumn{3}{|c|}{ Weathering grade } & SW & FR & $\mathrm{CW}$ & MW \\
\hline \multirow{3}{*}{$\begin{array}{c}\text { Uniaxial } \\
\text { compressive strength } \\
(\mathrm{MPa})\end{array}$} & \multicolumn{2}{|l|}{ Fossil surface } & 56.28 & 41.37 & 68.20 & 6.63 \\
\hline & \multirow{2}{*}{ Upper portion of inclined plane } & horizontal & 59.57 & 35.90 & 75.16 & 8.06 \\
\hline & & vertical & 64.06 & 50.81 & 76.16 & 6.91 \\
\hline
\end{tabular}

SW; slightly weathered, FR; fresh, CW; completely weathered, MW; moderately weathered, SD; standard deviation 


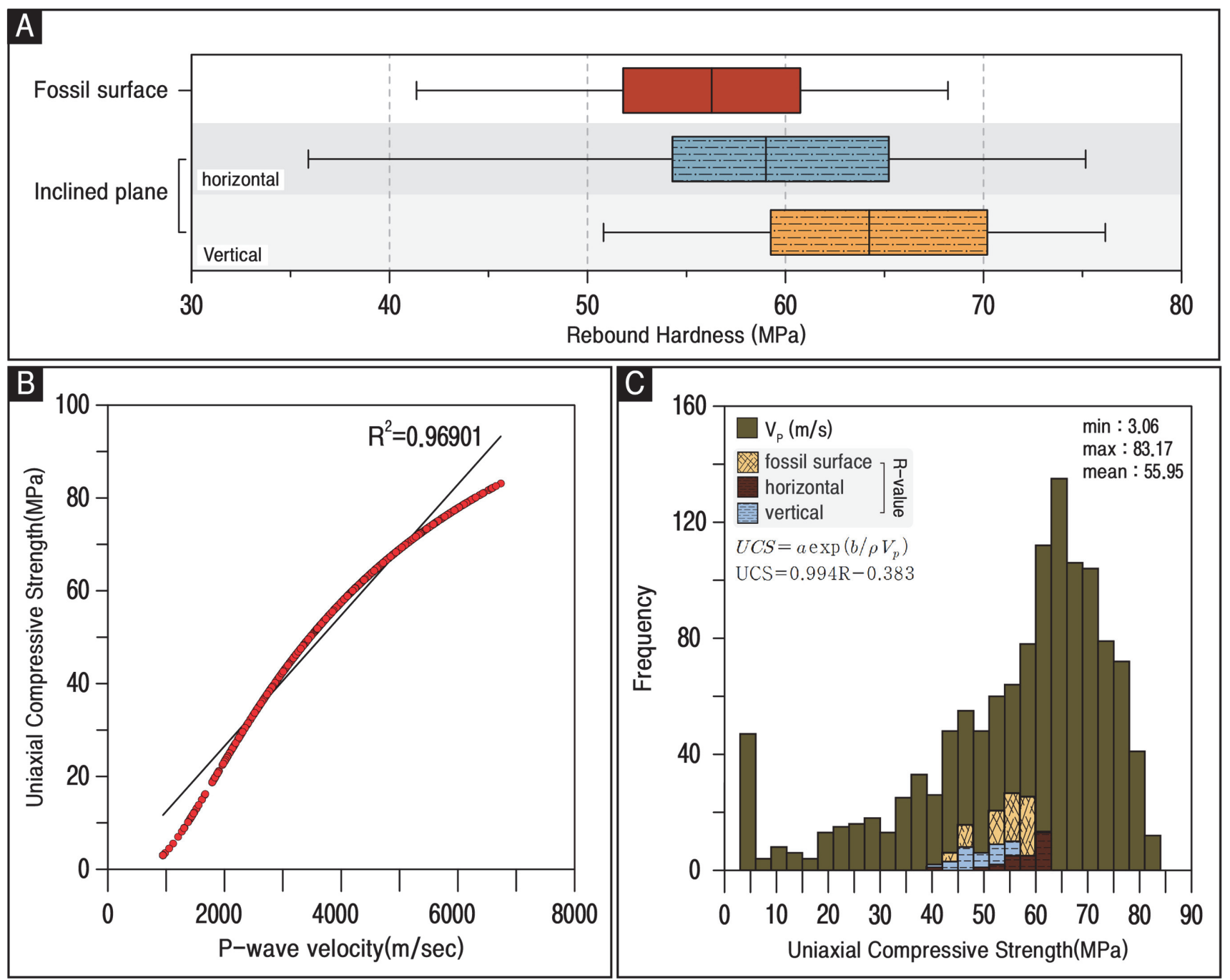

Fig. 11. Distribution of uniaxial compressive strength (UCS) on the rock surface for dinosaur track site in the study area and its relation to the ultrasonic velocity $\left(\mathrm{V}_{\mathrm{p}}\right)$. (A) Estimation of UCS based on Schmidt hammer rebound at each measuring point. (B) The UCS versus multiple P-wave. (C) Comparison of ultrasonic velocity with the calculated value of the rebound hardness. R; Schmidt hammer rebound number, $\rho$; density value.

Table 6. Proposed equations of predicting uniaxial compressive strength (UCS) for dinosaur track site in the study area

\begin{tabular}{ccccc}
\hline References & Equation & $\mathrm{a}$ & $\mathrm{b}$ & $R^{2}$ \\
\hline Moradian and Behnia & $\mathrm{UCS}=\mathrm{a} \exp \left(\mathrm{b} / \mathrm{V}_{\mathrm{p}}\right)$ & 165.05 & $-4,451.07$ & 0.70 \\
\cline { 2 - 5 }$(2009)$ & $\mathrm{UCS}=\mathrm{a} \exp \left(\mathrm{b} / \rho \mathrm{V}_{\mathrm{p}}\right)$ & 142.47 & $-9,560.57$ & 0.75 \\
\hline \multirow{2}{*}{$\begin{array}{c}\mathrm{UCS}=\mathrm{b}+\mathrm{aV} \mathrm{v}_{\mathrm{p}} \\
(2014)\end{array}$} & $\mathrm{UCS}=\mathrm{aV} \mathrm{p}_{\mathrm{p}}^{\mathrm{b}}$ & 0.0252 & -18.7287 & 0.57 \\
\cline { 2 - 5 } & $\mathrm{UCS}=\mathrm{b}+\mathrm{a}\left(\mathrm{V}_{\mathrm{p}} \gamma\right)$ & 0.0017 & 1.2900 & 0.58 \\
\end{tabular}

UCS; uniaxial compressive strength (MPa), Vp; P-wave velocity $(\mathrm{km} / \mathrm{s}), \rho$; density value

른 다양한 경험식이 제안되어 있다(Table 6). 이를 신성 리 화석지에서 획득한 초음파속도 측정값과 압축강도 추 정값의 결과를 비교하여 과소 및 과대평가된 것을 단계 적으로 소거하였으며, 가장 적합한 것으로 여겨지는
Moradian and Behnia(2009)의 제안식을 적용하였다.

우선 연구대상 화석지의 초음파속도와 추정식에 적용 하여 얻은 일축압축강도에 대한 두 변수의 상관도를 도 시한 결과, 피어슨 상관계수가 0.969 로 매우 양호한 관계 
를 갖는 것으로 나타난다(Fig. 11B). 또한 초음파속도 값 과 반발경도 측정값을 각각 일축압축강도로 산출하여 히 스토그램으로 도시하여 비교하였다(Fig. 11C).

이 결과, 전반적으로 초음파속도를 일축압축강도로 변 환할 때 상대적으로 높고 넓은 분포를 보여, 최소 $3.06 \mathrm{MPa}$ 에서 최대 83.17(평균; 55.95$) \mathrm{MPa}$ 의 범위로 측정되었다.

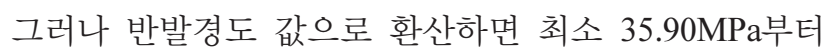
최대 76.16 (평균; 35.90$) \mathrm{MPa}$ 의 범위에 집중되는 양상을 확인할 수 있다.

연구대상 화석지는 미세한 호층을 이루는 퇴적암으로 구성되어 지층의 탈락에 의한 층리면의 박락과 불규칙한 절리가 발달하는 암반이다. Lee and $\operatorname{Kim}(2004)$ 은 혼펠스 화된 암석에서는 풍화정도가 약하게 나타난다고 하였다. 이는 열변질로 인해 경도가 커지고 암석의 밀도가 증가 하여 물이 암석내로 침투하는 것을 막아 상대적으로 기 계적인 풍화작용의 진행을 지연시키기 때문이다. 따라서 신성리 화석지는 열변질에 의해 혼펠스화되어 있어 다른 화석산지에 비해 물리적 풍화작용에 의한 영향은 비교적 낮은 것으로 판단된다.

\section{4. 보존방안 검토}

화석지와 같은 넓은 암반의 보존처리는 각각의 화석을 대상으로 진행하며 형상을 유지하는데 목적이 있다. 보 존처리 과정에서 모든 발자국의 손상유형을 확인하고 처
리방법을 설정하는 것은 시간적 및 경제적으로 매우 비 효율적이다. 이 연구에서는 발자국 화석에 발생한 손상 유형 중 보존처리가 필요한 물리적 손상을 기준으로 발 자국 화석의 보존처리 유형을 분류하였다(Table 7).

신성리 공룡발자국 화석은 대부분의 발자국에서 미세 균열과 박락으로 인한 손상이 가장 심하다. 일부 발자국 에서는 박리상 균열을 따라 발생한 박리가 형상을 변형 시킬 위험에 노출되어 있으며, 이 화석지에서 유일하게 구조상균열이 발생한 용각류 1 번 보행렬의 12 번째 발자 국은 균열을 따라 발생한 탈락 암편에 대한 보존처리를 수행하여 유실을 방지할 필요가 있다.

신성리 공룡발자국 화석에 적용이 필요한 보존처리를 기준으로 유형 $\mathrm{A}$ 부터 $\mathrm{D}$ 까지 4 개의 유형으로 구분하였다. 유형 $\mathrm{A}$ 와 $\mathrm{B}$ 는 접합이나 충전처리 없이 강화처리만 필요 하나, 유형 $\mathrm{C}$ 는 기초적인 강화처리와 박리부 충전이 요 구되며, 유형 $\mathrm{D}$ 는 강화처리 외에 구조상균열로 인한 접 합을 검토할 필요가 있는 것으로 분류하였다(Table 7).

각각의 보존처리 유형별로 살펴보면, 유형 $\mathrm{A}$ 는 미세균 열이 발생한 발자국에 대해 더 이상 균열이 진전되지 않 도록 강화처리가 필요한 경우이다. 유형 $\mathrm{B}$ 는 미세균열과 박락이 함께 발생한 발자국으로 전체적인 강화처리가 필 요한 것으로 판단하였다. 유형 $\mathrm{C}$ 는 미세균열과 박리가 발생한 발자국에 대해 강화와 충전이 요구되는 것이며, 유형 $\mathrm{D}$ 는 미세균열, 구조상균열 및 박리가 발생한 발자 국으로 강화, 접합 및 충전처리가 필요한 경우이다.

Table 7. Classification on deterioration types and method of representative treatments for all dinosaur footprint fossils in the study area

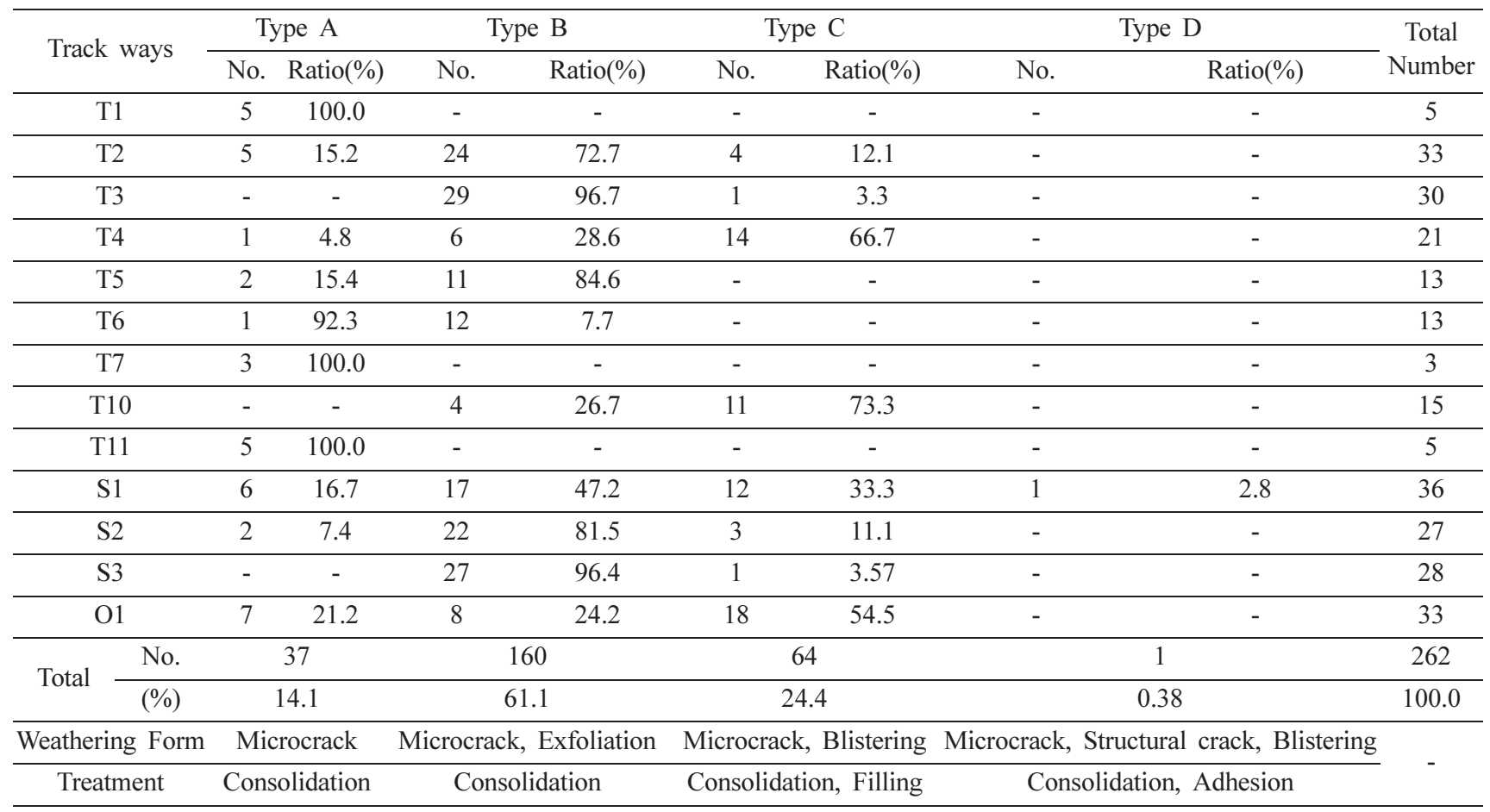




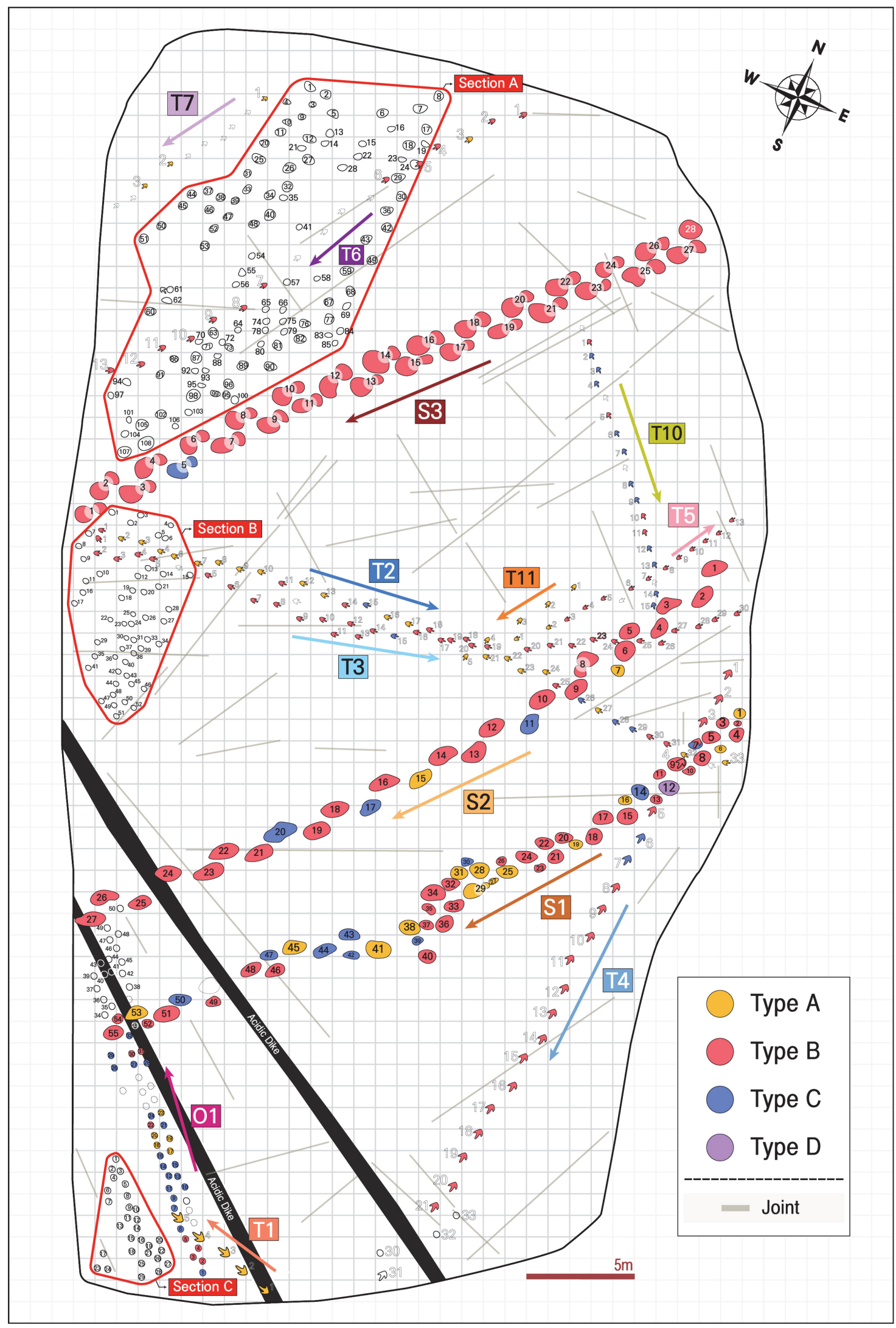

Fig. 12. Distribution map showing the suggestion types for conservation treatments of dinosaur track site in the study area. T; theropod trackways, S; sauropod trackways, O; ornithopod trackway. 
신성리 화석지에서 산출되는 총 262 개의 공룡발자국에 대해 손상양상에 따른 보존처리 유형을 설정하였다. 또 한 각 보존처리유형에 해당하는 공룡발자국을 종합적으 로 검토하여 전체적인 보존처리 유형의 도면을 제시하였 다(Fig. 12). 이를 바탕으로 보존처리유형별 점유율과 각 보행렬에 대한 손상유형별 점유율을 산출하였다(Table 7).

전체 발자국 화석 중에서 가장 높은 점유율을 보인 보 존처리 유형은 강화처리만 필요한 유형 $\mathrm{B}$ 로 약 $61.1 \%$ 를 차지한다. 유형 $\mathrm{A}(14.1 \%)$ 는 대부분의 보행렬에서 나타나 며, 유형 $\mathrm{B}$ 다음으로 높은 비율을 보인다. 유형 $\mathrm{C}$ 는 조 각류 발자국에서 다수 확인되었으며, 유형 $\mathrm{D}$ 는 $0.38 \%$ 로 가장 낮은 점유율을 갖는다(Table 7).

보행렬에 대한 보존처리 유형의 개수 및 점유율을 살 펴보면, 보행렬을 구성하는 모든 발자국이 유형 $\mathrm{A}$ 에 해 당하는 것은 $\mathrm{T} 1, \mathrm{~T} 7, \mathrm{~T} 11$ 번이다. 유형 $\mathrm{B}$ 는 전체 보행렬 뿐만 아니라 수각류와 용각류 보행렬 내에서도 가장 높 은 점유율을 보이며, 이 중에서 $\mathrm{T} 3, \mathrm{~S} 3$ 보행렬에서 각각 96.7\%와 96.4\%로 확인된다. 유형 C는 수각류 보행렬 중 $\mathrm{T} 10(73.3 \%)$ 과 조각류 보행렬 $\mathrm{O} 1(54.5 \%)$ 에서 절반 이상 의 비율을 보인다. 유형 $\mathrm{D}$ 는 $\mathrm{S} 2$ 보행렬(2.8\%)에서만 나 타난다(Table 7).

특히 균열지수가 8 내외로 나타난 공룡발자국(T4-15, $\mathrm{T} 5-5, \mathrm{~T} 6-4)$ 은 모두 유형 $\mathrm{B}$ 에 해당한다. 이와 같이 미세 균열이 진전될 경우 세편화될 수 있으며 박리와 박락을 수반할 수 있으므로 집중적인 강화처리와 예방조치가 필 요하다(Table 2, Figure 6).

또한 신성리 공룡발자국 화석지를 피복하고 있는 다양 한 표면오염물 중에서 표면에 도포된 백색페인트 및 합 성수지는 보존에 직접적인 영향을 미칠 수 있다(Figure 7D). 이는 단기적인 가시효과가 있으나 이들이 풍화되면서 암 편의 탈락을 유발하여 오히려 화석의 손상을 촉진한 사 례로 알려져 있기도 하다(Kong et al., 2011; Lim, 2014). 따라서 안정적 보존을 위해 앞서 제시한 분석 결과를 바 탕으로 도포된 페인트와 합성수지를 제거하고, 암석에 손 상을 최소화 할 수 있는 방법을 충분히 논의하여 대체 방안을 적용해야 할 것이다.

한편 연구대상 화석지의 물성측정 결과, 전체적으로 혼 펠스화되어 있어 대부분 건전하지만 화석지에 관입한 암 맥과 암석학적 특성으로 인해 표준편차가 크다(Table 5). 이 중 높은 풍화도를 보이는 지점에 분포하는 보행렬(T1, $\mathrm{S} 1, \mathrm{~S} 2, \mathrm{O} 1)$ 의 일부 발자국은 향후 손상유형에 관계없이 다양한 변화가 발생할 수 있음을 감안하여 보존처리를 수행하는 것이 중요하다(Figure 10).

신성리 공룡발자국 화석지의 지속적 보존을 위해 앞서 제안한 보존처리 방법을 실행하기 위해서는 먼저 이 연
구에서 제시한 보존과학적 진단과 손상도 평가 등의 자 료를 근거로 보존처리 임상실험을 통해 보다 안정적인 방안을 검토해야 한다. 또한 화석지는 야외에 노출되어 있어 자연적 요인에 쉽게 영향을 받기 때문에 보존처리 를 시행하더라도 계속적인 모니터링을 통한 감시가 항시 이루어져야 한다. 따라서 일시적인 보존처리로 완성되는 것이 아니라, 객관적이고 연속적인 관리를 위해 체크리 스트를 바탕으로 전문가의 정기점검이 필요할 것이다.

\section{5. 결 언}

1. 청송 신성리 화석지 퇴적암층의 전체적인 암상은 회 색, 녹색 또는 청회색 사암과 이암 및 미사암 등으로 구 성된다. 공룡발자국 화석은 연구지역의 사곡층에서 흔히 산출되는 엽층 내지 박층으로 발달한 세립 사암 또는 미 사암과 이암의 교호대에 분포한다. 공룡발자국의 모암은 전체적으로 열변질을 받아 혼펠스화되어 있다.

2. 공룡발자국 화석지의 중요한 물리적 손상양상으로 는 균열(미세, 박리상, 구조상), 절리, 박리 및 박락 등이 확인되었다. 이 공룡발자국의 손상지도를 바탕으로 손상 도를 평가한 결과, 전반적으로 미세균열과 박락을 제외 하면 다른 손상유형은 거의 나타나지 않는다. 수각류와 용각류 발자국은 박락에 의한 손상률이 적었으나 조각류 에서 상대적으로 광범위하게 나타났다.

3. 이 화석지에서 이차적 손상으로 대별되는 풍화특성 을 파악하기 위해 표면오염물(흑색, 황색, 갈색, 페인트흔) 을 정밀 분석하였다. 각 지점에 대해 P-XRF 측정 후 SEM-EDS 분석을 수행하여 비교 및 검토하였다. 이 결 과, 흑색오염물은 모든 곳에서 신선한 지점에 비해 $\mathrm{S}, \mathrm{Mn}$ 및 $\mathrm{Ca}$ 함량이 높았다. 공룡발자국에 도포된 백색 페인트 는 높은 $\mathrm{Ti}$ 함량을 갖는 것으로 보아 이산화티타늄 $\left(\mathrm{TiO}_{2}\right)$ 을 안료로 사용한 페인트로 해석하였다.

4. 화석지를 구성하고 있는 암석의 물성을 파악하기 위 해 초음파속도 측정을 실시하였다. 화석지 전체의 초음 파 속도는 $710 \sim 5,000 \mathrm{~m} / \mathrm{s}$ 의 넓은 분포를 보였으며 평균 $3,075 \mathrm{~m} / \mathrm{s}$ 로 산출되었다. 또한 남쪽에 관입한 암맥의 초음 파 속도는 700 750(평균 723) $\mathrm{m} / \mathrm{s}$ 로 높은 풍화도를 보인 다. 전체 화석지의 평균 풍화도지수 $(\mathrm{K})$ 는 0.14 로 신선한 단계(FR)에 해당하여, 전반적인 모암의 물성은 건전한 것 으로 판단된다.

5. 화석지 암반에 대한 안정성 평가를 위해 모암의 표 면, 경사면 상부의 수평면 및 수직면을 대상으로 반발경 도를 측정하여, 이를 암석의 일축압축강도로 환산하였다. 이 결과, 경사면 상부층 수직면에서 가장 넓고 높은 분 포범위를 보였다. 한편 화석층의 기반암 최상부면은 상 
대적으로 낮고 좁은 분포를 나타냈다.

6. 연구대상 화석지에서 획득한 초음파속도에 대하여 다양한 추정식을 적용해 일축압축강도로 환산하였다. 이 를 국제암석역학회의 기준에 적용하여 평가한 결과, 암 석의 강도는 대부분 보통암 내지 경암에 해당하였으며 이는 전반적으로 양호한 물성임을 지시한다. 이 퇴적암 층은 열변질에 의해 혼펠스화되어 있어 다른 화석산지에 비해 물리적 풍화작용에 의한 영향은 상대적으로 낮은 것으로 판단하였다.

7. 신성리 화석지의 효율적인 보존관리를 위해 발자국 에 발생한 손상유형 중 보존처리가 필요한 균열(미세, 구 조상), 박리, 박락을 기준으로 총 262개의 발자국에 대한 보존처리 유형을 분류하였다. 이 결과, 유형 $\mathrm{B}$ 가 가장 높 은 점유율을 보였으며 유형 $\mathrm{D}$ 는 $0.38 \%$ 로 가장 낮았다. 유형 $\mathrm{A}(14.1 \%)$ 는 대부분의 보행렬에서 나타나며, 유형 B 다음으로 높은 비율을 차지하였다. 따라서 지속적인 모 니터링과 이를 반영한 보존관리 체계가 정립되어야 할 것이다.

\section{사 사}

이 결과는 2020년 경상북도 청송군의 지원을 받아 수 행한 연구의 일부임을 명기하며 이에 깊은 사의를 표한 다. 또한 원활한 조사와 연구가 가능하도록 지원해 주신 청송군 관광정책과 주성옥 학예연구사께도 깊이 감사드린다.

\section{References}

Kong, D.Y., Lim, J.D., Wohn, K.Y., Ahn, J.H. and Kim, K.S. (2011) Application of $3 \mathrm{D}$ digital documentation to natural monument fossil site. Journal of the Korea Contents Association, v.11, p.492-502. doi: 10.5392/JKCA.2011.11.11.492. (in Korean with English abstract)

Choi, G.H. and Baek, S.C. (2014) Predicting the uniaxial compressive strength and Young's modulus of rocks using ultrasonic velocity. Journal of the Korean Geoenvironmental Society, v.15, p.53-58. doi: 10.14481/jkges.2014.15.2.53. (in Korean with English abstract)

Haramy, K.Y. and De Marco, M.J. (1986) Use of the Schmidt hammer for rock and coal testing. International Journal of Rock Mechanics and Mining Sciences \& Geomechanics Abstracts, v.23, p.132. doi: 10.1016/0148-9062(86)90704-7.

Iliev, I.G. (1966) An attempt to estimate the degree of weathering of intrusive rocks from their physical-mechanical properties. Proceedings of the International congress on Rock Mechanics, v.1, p.109-114.

Jo, Y.H. and Lee, C.H. (2011) Making method of deterioration map and evaluation techniques of surface and three-dimensional deterioration rate for stone cultural heritage. Journal of Conservation Science, v.27, p.251-260. (in Korean with English abstract)

Jo, Y.H. and Lee, C.H. (2014) Establishment of ultrasonic measurement method for stone cultural heritage considering water content and anisotropy. Journal of Conservation Science, v.30, p.467-480. doi: 10.12654/JCS.2014.30.4.15. (in Korean with English abstract)

Jo, Y.H. and Lee, C.H. (2015) A study on selection of ultrasonic transducer and contact material for surface irregularities of stone cultural heritage. Journal of Conservation Science, v.31, p.267278. doi: 10.12654/JCS.2015.31.3.07. (in Korean with English abstract)

Kim, H.J., Hwang K.G., Jeong, H.H., Ahn, H.Y., Choi, C.U., Lim, H.S., Choi, T.J., Chae, Y.U. and Paik, I.S. (2019) Dinosaur trackbearing deposits in Sagok Formation (Cretaceous) at Sinseong-ri, Cheonsong-gun, Korea: Occurrences and paleo environments. Journal of the Geological Society of Korea, v.55, p.495-511. doi: 10.14770/jgsk.2019.55.5.495. (in Korean with English abstract)

Lee, C.H. and Jo, Y.H. (2017) Correlation and correction factor between direct and indirect methods for the ultrasonic measurement of stone samples. Environmental Earth Sciences, v.76, 477. doi: /10.1007/s12665-017-6810-7.

Lee, C.H., Jo, Y.H. and Chun, Y.G. (2009) Establishment of ultrasonic measurement and correlations of direct-indirect method for weathering evaluation of stone cultural heritage. Journal of Conservation Science, v.25, p.233-244. (in Korean with English abstract)

Lee, C.H., Jo, Y.H. and Kim, S.D. (2012) Three-dimensional image analysis, deterioration evaluation and scientific conservation treatment of the Daechiri dinosaur trackways in Haman County, Korea. Journal of the Geological Society of Korea, v.48, p.179191. (in Korean with English abstract)

Lee, G.H., Lee, C.H. and Yang, H.R. (2020) Application experiments of consolidation treatment for pelitic sedimentary rocks: Bird track fossils in Haman formation. Economic and Environmental Geology, v.53, p.87-98. doi: 10.9719/EEG. 2020.53.1.87. (in Korean with English abstract)

Lee, G.H., Park, J.H. and Lee, C.H. (2019) Conservation scientific diagnosis and evaluation of bird track sites from the Haman Formation at Yongsanri in Haman, Korea. Korean Journal of Cultural Heritage Studies, v.52, p.74-93. doi: 10.22755/ kjchs.2019.52.3.74. (in Korean with English abstract)

Lee, S.H, and Kim, S.J. (2004) Weathering characteristics of sedimentary rocks affected by periodical submerging. Journal of the Mineralogical Society of Korea, v.17, p.23-35. (in Korean with English abstract)

Lim, J.D. (2014) A case study on the preservation of dinosaur fossil sites and application plans as geological heritage. Journal of the Geological Society of Korea, v.50, p.151-163. (in Korean with English abstract)

Moon, J.M. (2011) Dinosaur tracks of the Cretaceous Sagok Formation at Sinseong-ri, Andeok-myeon, Cheongsong-gun, Gyeongsangbuk-do, Korea. Thesis of Master's Degree, 
Kyungpook National University, p.21. (in Korean with English abstract).

Moradian, Z.A. and Behnia, M. (2009) Predicting the uniaxial compressive strength and static Young's modulus of intact sedimentary rocks using the ultrasonic test. International Journal of Geomechanics, v.9, p.14-19. doi: 10.1061/(ASCE)15323641(2009)9:1(14).

Son, M., Kim, J.S., Hwang, B.H., Lee, I.H., Kim, J.M., Song, C.W. and Kim, I.S. (2007) Paleogene dyke swarms in the eastern
Geoje island, Korea: Their absolute ages and tectonic implications. The Journal of the Petrological Society of Korea, v.16, p.82-99. (in Korean with English abstract)

Yoo, J.H., Lee, C.H. and Eo, E.I. (2012) Evaluation of deterioration diagnosis and conservation environments of the large and the giant dinosaur footprint fossils in Haenam Uhangri, Korea. Journal of the Geological Society of Korea, v.48, p.325-340. (in Korean with English abstract) 